\title{
The middle Palaeolithic lithic industry of Roc de Combe (Payrignac, Lot, France), A new example of Denticulate Discoïd Mousterian
}

L'industrie lithique du Paléolithique moyen récent de Roc de Combe (Payrignac, Lot, France), un nouvel exemple de Moustérien Discoïde à denticulés

Maria Lorenzo Martinez, Jean-Guillaume Bordes and Jacques Jaubert

\section{OpenEdition}

Journals

\section{Electronic version}

URL: http://journals.openedition.org/paleo/3011

DOI: 10.4000/paleo.3011

ISSN: 2101-0420

\section{Publisher}

SAMRA

\section{Printed version}

Date of publication: 28 December 2014

Number of pages: 101-124

ISSN: 1145-3370

\section{Electronic reference}

Maria Lorenzo Martinez, Jean-Guillaume Bordes and Jacques Jaubert, «The middle Palaeolithic lithic industry of Roc de Combe (Payrignac, Lot, France), A new example of Denticulate Discoïd Mousterian », PALEO [Online], 25 | 2014, Online since 02 June 2016, connection on 07 July 2020. URL : http:// journals.openedition.org/paleo/3011; DOI : https://doi.org/10.4000/paleo.3011

This text was automatically generated on 7 July 2020 . 


\title{
The middle Palaeolithic lithic industry of Roc de Combe (Payrignac, Lot, France), A new example of Denticulate Discoïd Mousterian
}

\author{
L'industrie lithique du Paléolithique moyen récent de Roc de Combe (Payrignac, \\ Lot, France), un nouvel exemple de Moustérien Discoïde à denticulés
}

Maria Lorenzo Martinez, Jean-Guillaume Bordes and Jacques Jaubert

We wish to thank Jean-Jacques Cleyet-Merle, director of the MNP and his staff for authorizing one of us (M.L.M.) to study this series as part of a Masters 2 dissertation at Bordeaux 1 University. Special thanks to André Morala and Alain Turq for their precise and competent advice, particularly in relation to the raw materials, as well as their roles in the Museum. And, generally to the entire Museum staff for their considerable help in washing-marking part of this series (Bernard Nicolas and Peggy Jacquement). Sincere thanks from the three authors to Jean-

Philippe Rigaud for his kind hospitality and interest in our work, and for information concerning his excavation recollections at Roc de Combe. We also thank Gauthier Devilder (CNRS MOM-Lyon and PACEA) for his excellent line drawings. Finally, thanks to the three reviewers for their informed, appropriate and complementary advice, which contributed to improving the initial version of the manuscript.

\section{1 - Introduction}

1 The techno-economic characterization and the chronological position of the last Mousterian techno-complexes in south-western France has been a popular and dynamic research theme for the past decade (e.g. Soressi 2002; Slimak 2004; Lahaye 2005; Thiébaut 2005; Jaubert et al. 2011; Gravina et al. 2012; Richter et al. 2012). This is 
due, in particular to the fact that these techno-complexes provide evidence of the link between the last Neanderthals and the first recent Palaeolithic cultures; the Chatelperronian and the Aurignacian. A recent study of the site of Roc de Combe (Payrignac, Lot), ${ }^{3}$ focusing on the unpublished Mousterian levels (Lorenzo Martinez 2012) is part of this impetus, following on from the study of the initial (Chatelperronian) and early Upper Palaeolithic levels of the site (Bordes 2002).

2 The context was favourable to the analysis of this material on several accounts. First of all, the reference collections are kept in the Musée National de Préhistoire (Les Eyziesde-Tayac). Like other collections, they are available for reexamination, using modern laboratory methods (taphonomy, archaeozoology, archaeopetrography, lithic technology or technology in hard animal matter, refits...), or even field methods (geoarchaeology, dating...). In this context, the series from Roc de Combe had only been partially exploited, mainly by François Bordes and his team, and published as contributions to different regional overviews (Bordes 1972, 1981; Grayson and Delpech 2008). At the same time, several major Mousterian archaeosequences from Perigord and Charente were also recently reexamined in the same aim, or even entirely restudied (La Quina, Fontéchevade, Combe-Capelle, Pech de l'Azé I, IV, Roc-de- Marsal, La Ferrassie...).

3 The Mousterian from Roc de Combe is part of this revaluation as the purpose of the study of this important sequence is to publish the data in regional reviews of the Mousterian in the Aquitaine Basin (e.g. Turq et al. 2008) and, more generally, in southwestern Europe.

4 Several evaluations of the series from the Mousterian levels had been carried out before the present contribution. The first of these was by François Bordes himself, who published a short note in his "Leçons sur le Paléolithique" (Bordes 1984), suggesting an uncertain attribution to the Acheulean Tradition Mousterian (MTA). One of us wrote about the zone above the collapsed or classical sequence (I to K) of Roc de Combe: that "[inside the cave] the Mousterian ("9" or " $\mathrm{M}$ " or "Mousterian from the top" from markings on bags and excavation notebooks) is poor in this zone, as the excavation stopped at the top of it due to the large collapsed blocks. It is clearly different to the two previous industries on account of considerable quartzite debitage, a raw material absent from the overlying layers (...); its typology (side scrapers and denticulates); debitage (mainly discoid, but with some evidence of Levallois)." (Bordes J.-G. 2002, p. 68). And, further on, about zone 2 (slope: base of A to E): "The following observations should be quantified by a more systematic analysis. We can nevertheless observe that this material corresponds to a homogeneous Mousterian industry, identical to that described for the upper part of the site (...): a clearly dominant discoid débitage (Boëda 1993), oriented towards the production of pseudo-Levallois points, with rare products retouched to form transverse or double offset side scrapers. Many denticulates were made on thick flakes by adjacent Clactonian notches. Several Levallois flakes are present, often in good quality Senonian flint. The rest of the debitage is mainly in medium quality Tertiary flint, of much poorer quality than the flint used during the Chatelperronian and Aurignacian at the site. Another difference with the Upper Palaeolithic industries is the substantial proportion of quartzite debitage. Typologically, this industry is a Mousterian with denticulates and non-Levallois débitage" (op. cit. p. 70) 
5 It was thus necessary to develop this assessment through a more detailed quantitative study in order to characterize this assemblage, and place the series in the recently revised Discoid débitage ${ }^{4}$ with denticulates (Thiébaut 2005, 2007); then, to contribute via this Roc de Combe Mousterian to better defining the archaeosequences of the southwest of France, where this lithic techno-complex occurs after the MTA (Jaubert 2010, 2012), above the Levallois and Quina complexes (Turq et al. 2008; Turq, Jaubert 2008).

\section{2 - Presentation of the site and the studied series}

\section{1 - Geographic and geological contexts}

Roc de Combe (Payrignac, Lot) is located on the eastern border of the Aquitaine Basin, between the Upper Cretaceous Perigord formations (Dordogne) on one side, and the harsh Quercy (Lot) Jurassic plateaus on the other, about ten kilometres northwest of Gourdon ( $1^{\circ} 20^{\prime} 45 \mathrm{E} ; 44^{\circ} 46^{\prime} 18 \mathrm{~N}, 150 \mathrm{~m}$ NGF) (fig.1). The small cave opens out at the foot of a Coniacian limestone hill, capped by Tertiary weathered rock, a formation locally known as "pech".

7 The modest cavity extends laterally into a south-facing rock shelter, overlooking a dry glen, which is itself a tributary of the Dordogne. The Dordogne Valley is located $6 \mathrm{~km}$ to the north. This zone is thus a geographic, geological and ecological zone of transition (ecotone) between Perigord to the west and Quercy to the east.

\section{2 - History of work at the site}

8 In 1950, Jean Labrot discovered the cave and bought the plot, then opened a test pit in 1959. This initial work revealed the range of the sequence - from the Mousterian to the Gravettian - and incited F. Bordes and his team to excavate the site for three months during the summer of 1966, with the site inventor and owner. After the first season, a dispute between the two men ended the excavation. The site was first published as a note (Bordes and Labrot 1967), and then included in an overview of the "Perigordian" (Bordes 1968). At the same time as work carried out by F. Champagne and R. Espitalié at the neighbouring site of Piage (Fajoles, Lot: Champagne and Espitalié 1967), F. Bordes identified his famous "interstratification" between the Chatelperronian (known at the time as the "Lower Perigordian") and the Aurignacian, backing up the then controversial model of parallel lines between the "Perigordian" and "Aurignacian" (Peyrony 1933; Bordes 1968; Rigaud 2000; Klaric 2003). This work brought to light an interesting sequence extending from the Recent Mousterian to the Upper Palaeolithic: Chatelperronian, Aurignacian and Gravettian (fig. 2).

Henri Laville incorporated the Roc de Combe sequence into his thesis as a long note, although he had only glimpsed the base of the sequence with the Mousterian level(s) (Laville 1969). Therefore, unlike many other regional sequences, no geological revision of Roc de Combe was carried out with updated concepts and methods, such as those elaborated by J.-P. Texier (Texier 2009).

The excavation followed the usual strategy for this type of geomorphological context: creation of a trench perpendicular to the cliff, from the talus to the interior of the cave, 
over a total surface of about 20 square metres (Bordes and Labrot 1967; Grayson and Delpech 2008) (fig. 3).

Figure 1- Location of Roc de Combe.

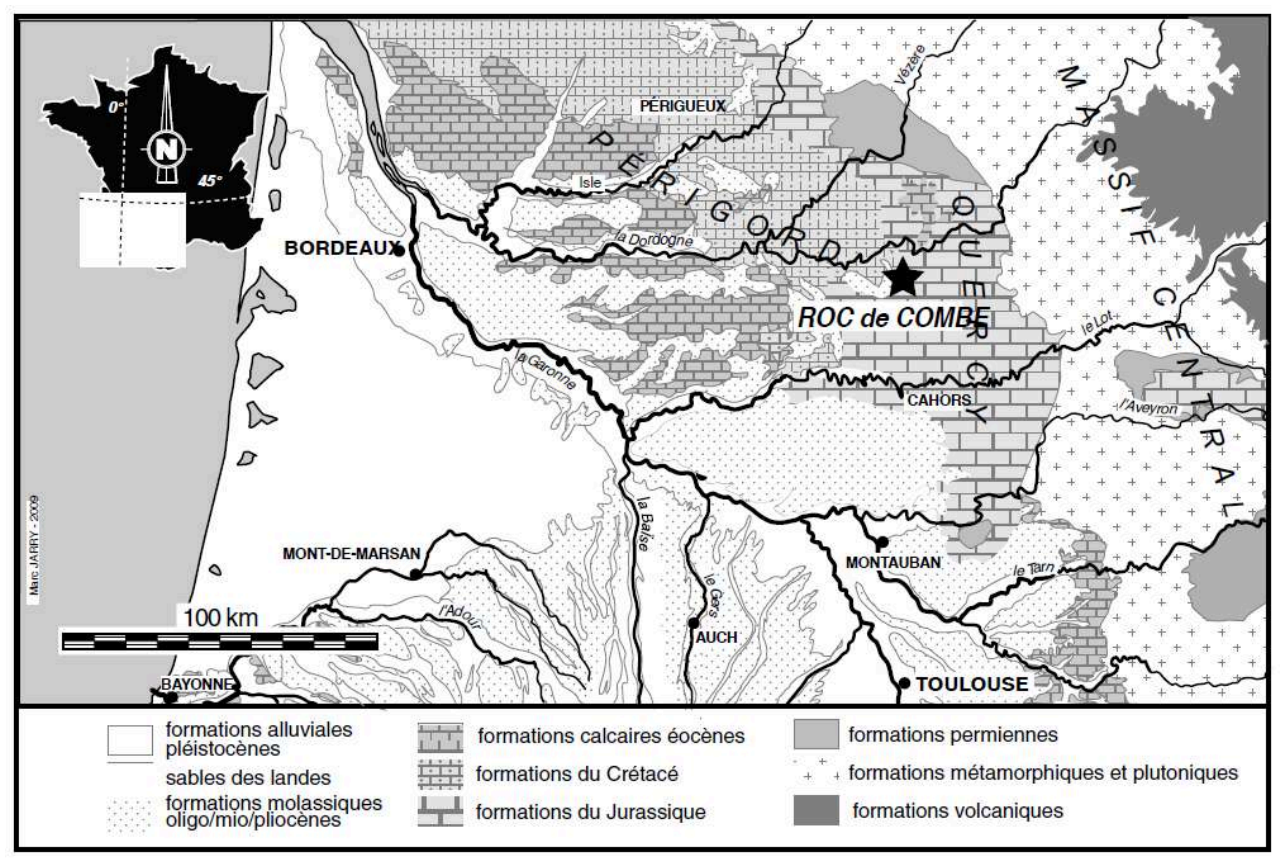

Figure 2 - Roc de Combe (Lot). Sagittal projection of coordinated objects and delimitation of zones 1, 2 and 3 (after Bordes 2002, modified).

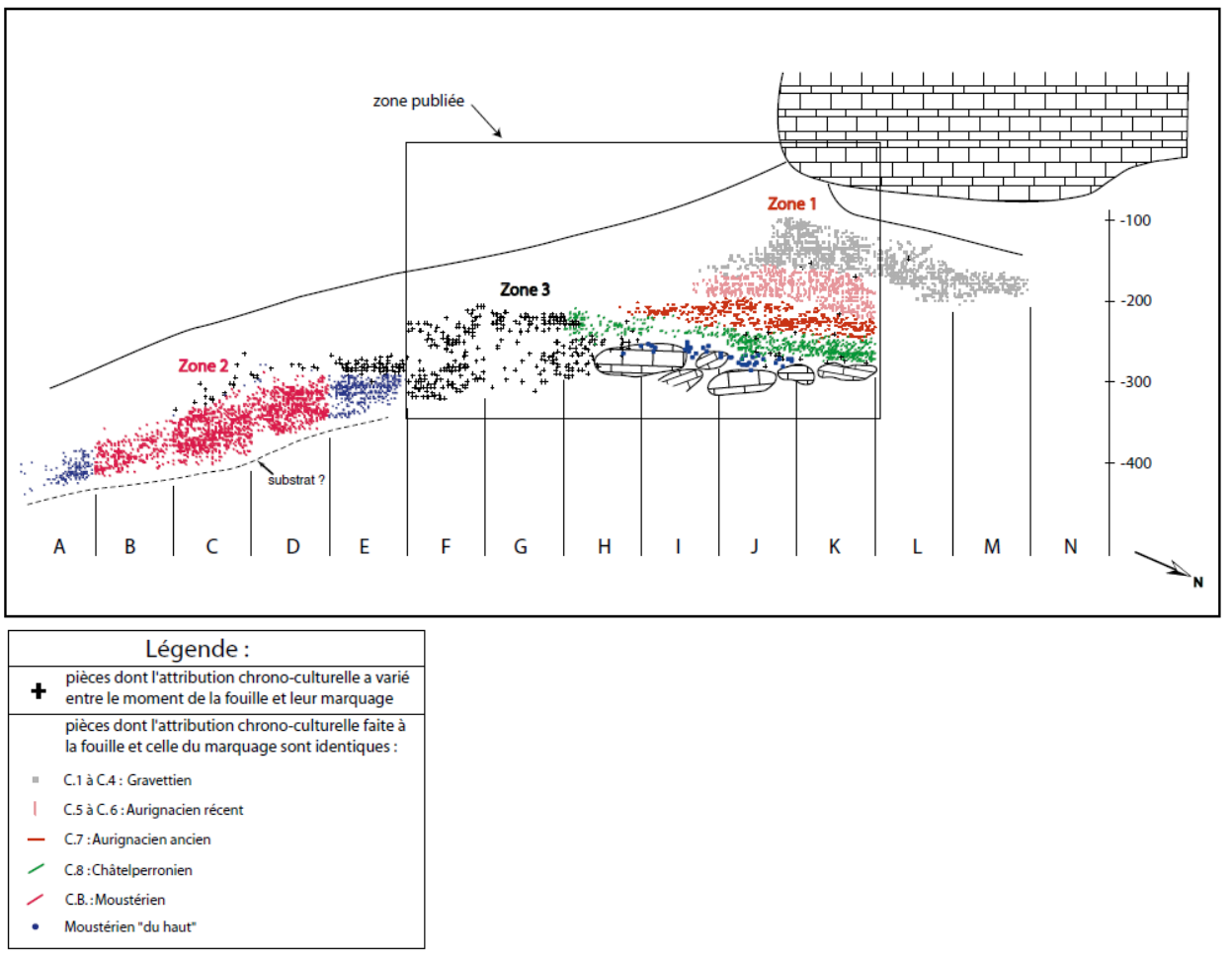

11 For the Mousterian levels in particular, some of the pieces were recorded three dimensionally, but most of the remains were not recorded or simply collected per layer 
or square metre. Dimensions were used as the criteria for recording pieces, but were subjectively evaluated by each excavator (pers. com. J.-Ph. Rigaud). Unlike for the Upper Palaeolithic, no sieving was carried out for the Mousterian and the fraction less than $6 \mathrm{~mm}$ is thus absent from the series. However, note that in some squares, the excavation was quite modern, as over 4,000 lithic objects and faunal elements were recorded in the Mousterian levels.

The sequence was first reevaluated by J.-Ph. Rigaud (2000), then by one of us (Bordes 2002). This latter reexamination enabled us to define three zones, differentiated on the basis of their sedimentary history and archaeological content (Zone 1 / classical sequence; Zone 2 / Mousterian and, between these two zones, Zone 3 / Interstratification). The taphonomic analysis of the series, with the exception of the Gravettian, contributed to calling into question this famous interstratification, the zone defined as not containing any level in coherent primary position. In addition, this study showed that two Mousterian assemblages could be identified at Roc de Combe (fig. 2):

- a modest batch of pieces of Mousterian appearance from zone 1, directly below the Chatelperronian, around and behind the present-day entrance of the cave, which we will call level 9. This assemblage yielded some elements attributable to the Discoid method, whereas others come from a Levallois debitage system;

- a substantial assemblage of lithic and bone remains, located in the slope in front of the site (zone 2 supra), which can be further divided into two:

- at the top, rare pieces with Upper Palaeolithic characteristics were found alongside pieces with a Middle Palaeolithic appearance. These artefacts are covered in gritty brown sediment. It is not impossible that they may partly come from spoil from the Labrot excavations, spread out on the slope (Bordes 2002 op. cit.).

- the lithic industry is homogeneous in the rest of the deposits, defined by a Discoid debitage concept, with a toolkit dominated by denticulate tools and notches. The surrounding sediment in this complex is yellow, grainy or gritty.

13 A rough stratigraphy of this complex was established during the excavation, but will not be reused here for several reasons: subsequent vegetation; homogeneous lithic material; uncertain limits according to the excavators themselves, particularly on account of marked carbonated incrustation; excavation of the Labrot spoil probably included in an archaeological sequence. The most likely hypothesis for the formation of this complex would be post-depositional redistribution (Bordes 2002). Up until now, the fauna from this Mousterian complex is still unpublished. Therefore we have no evidence of the number of occupations in this complex. 
Figure 3 - Roc de Combe (Lot) - Plan of the site. In blue: excavated area of the cave and estimated total number of Mousterian pieces. In grey: squares studied in this work. Shades of grey (from darker to lighter shades) represent the number of pieces. Left: all the sampled material counted per square and layer. In red: number and proportion of pieces coordinated per square. After Bordes 2002, modified.

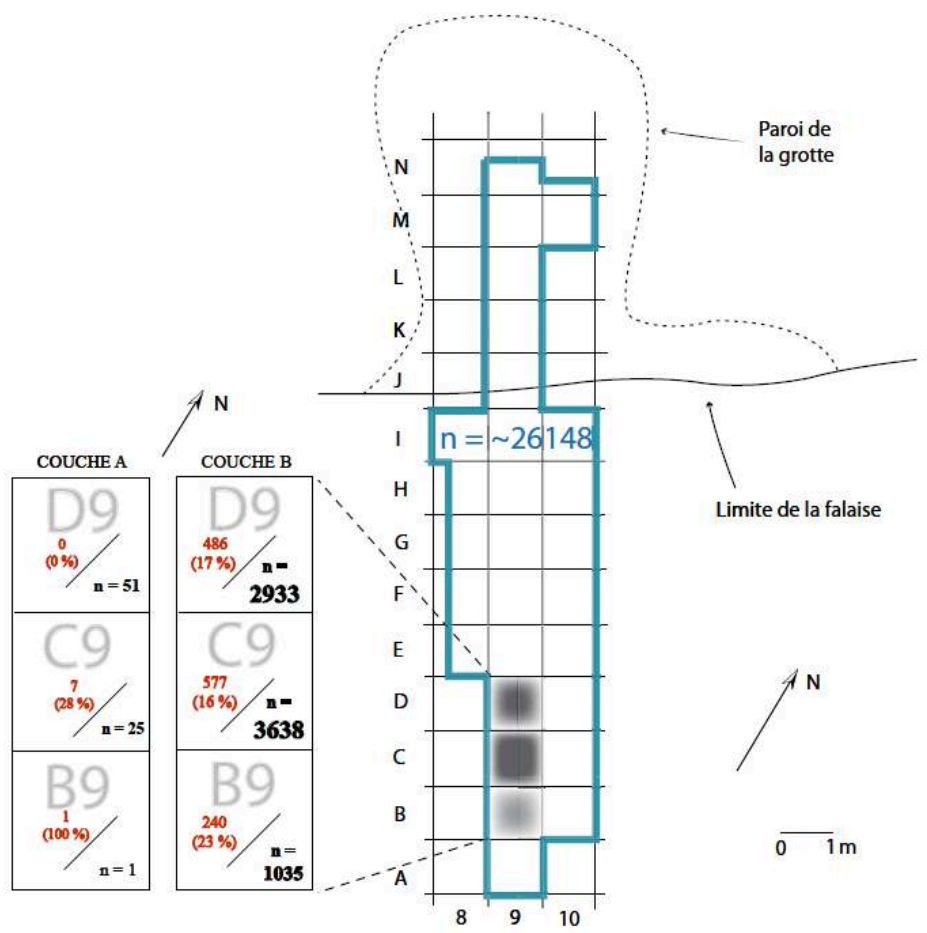

\section{3 - The F. Bordes series from the MNP and sampling strategy}

14 We estimated the Mousterian lithic industry currently deposited in the Musée National de Préhistoire (MNP, Les Eyzies-de-Tayac) at over 26,000 artefacts. Due to the time limits imposed for our university research ${ }^{5}$, but also for the aforementioned reason, we took a sample over three square metres considered to be representative in terms of topography and archaeological density, made up of a total of at least 7,610 pieces, or 43 $\%$ of the lithic material from zone 2 and a little less than a third of the whole Mousterian collection (29\%) (fig. 3 and tab. 1).

\section{4 - Methodology, archaeopetrographic context}

\subsection{1 - Concepts and typo-technological vocabulary}

The study of the series included a sorting phase to divide the pieces into the different blank categories used in Francophone literature for the Middle Palaeolithic (Geneste 1985; Turq 1992, 2000; Boëda 1993; Jaubert 1994; Locht and Swinnen 1994; Mourre 2003; Slimak 2003; Locht 2004; Faivre 2008). A corpus of metric data was established, comprising the length, width and sometimes the thickness, along the debitage axis, of the pieces of interest for this study (cores, retouched blanks, specific Discoid debitage products). Cores were analyzed using accepted descriptors, which will be itemized 
below. Retouch observation is based on the work of Inizan, Reduron-Bollinger, Roche 1995 and Thiébaut 2005 for the denticulate tools.

Our lithological inventory is largely based on earlier research into the early Aurignacian from the same site (Bordes 2002), as well as on diverse seminal works, for all periods (Morala 1984; Geneste 1985; Séronie-Vivien and Séronie-Vivien 1987; Astruc 1990; Turq, Antignac, Roussel 1999; Turq 2000), or more recently (Faivre 2008; Turq 2000; Turq and Morala 2013). The petrographic analyses were carried out with the help of A. Morala and A. Turq (MNP-PACEA), whom we wish to thank here for their help.

\section{3 - The Mousterian lithic industry}

\section{1 - Raw materials}

The average dimensions of the abandoned objects are similar for the different raw materials. Weight data are not taken into consideration as they would have been biased by the fact that the patina could have modified the initial mass of the objects. The quantified data presented below are the number of pieces for each category. The Roc de Combe Mousterians mainly used Tertiary chalcedony, which accounts for $79 \%$ of the studied series, then small blocks of Senonian flint (grey/black and beige), $10 \%$ of the whole series (tab. 1). These are followed by quartz and metaquartzites ( $8 \%)$. Very small quantities of diverse other types of flint are present: Infralias jasper, Maastrichtian flint, known as "Bergeracois", Lower Turonian known as "Fumélois", Portlandian flint or flint from Missère (Lot), Bathonian flint and lastly, Lower Coniacian flint, called "Gavaudun" (probably present). These diagnoses require confirmation based on more detailed petrographic analyses. Several other types of non-crypto-crystalline materials are marginally represented: basalt, ferruginous sandstone and sandstone. Given the potential outcropping sources of these materials, procurement is largely local (sensu Geneste 1985). The acquisition zone of $99 \%$ of the materials recorded in the series is probably confined to a radius of less than $10 \mathrm{~km}$, including the Marcillande and Germaine valleys and part of the Dordogne Valley. In this respect, Roc de Combe has a lot in common with Grotte Vaufrey, which is located about 15 kilometres away (Geneste 1988).

This spectrum includes Tertiary lacustrine flint and jasper (present in the Dordogne alluviums), grey/black Senonian flint, Portlandian and lastly alluvial quartzites or basalt, as well as sandstones from the plateaus. However, the presence of flint from an intermediate regional zone is also evidenced, made up of several varieties of Jurassic flint. Lastly, the Roc de Combe Mousterians also used more distant provisioning zones or exchanges (from 40 to $70 \mathrm{~km}$ ), for Lower Turonian flint, known as "Fumélois", Lower Coniacian (Gavaudun) - although the latter requires confirmation - and lastly Maastrichtian "Bergeracois" type flint. A more detailed petrographic characterization of certain pieces will lead to a more accurate petrographic description. However, these first assessments provide a solid documentary foundation and bring to light several major traits of this series:

- a large majority of local materials, with a predominance of relatively mediocre quality materials, but with effective cutting edges;

- acquisition decreases quantitatively as the distance of the lithic raw material sources from the site increases; 
- blocks were collected for uses other than knapping (sandstone, granite);

- presence of several rock types from distant sources, but in marginal quantities: rare and remarkable flints, such as the Fumélois, which is well evidenced, unlike the Gavaudun, which requires special attention even though it is only represented by a single specimen; and lastly the "Bergeracois" (Maastrichtian, cf. infra).

Table 1 - Roc de Combe (Lot) - Technological counts by raw material.

\begin{tabular}{|c|c|c|c|c|c|c|c|c|c|c|c|c|c|}
\hline \multirow{2}{*}{\multicolumn{2}{|c|}{ Catégories technologiques }} & \multicolumn{3}{|c|}{ Calcédoine tertisire } & \multicolumn{3}{|c|}{ Silex sénonien } & \multicolumn{3}{|c|}{ Autres silex } & \multicolumn{3}{|c|}{ Quartzites } \\
\hline & & Effectif & $\%$ & $\begin{array}{l}\text { \% par rapport í } \\
\text { la série totale }\end{array}$ & Effectif & $\%$ & $\begin{array}{l}\text { \% par rapport ì } \\
\text { la serie totale }\end{array}$ & Effectif & $\%$ & $\begin{array}{l}\% \text { par rapporti } \\
\text { la serie totale }\end{array}$ & Effectif & $\%$ & $\begin{array}{l}\text { \% par rapport i } \\
\text { la série totale }\end{array}$ \\
\hline \multirow{3}{*}{ Eclats a surface naturele } & Entames & 162 & $2.6 \%$ & $2.1 \%$ & 44 & $5.6 \%$ & $0.6 \%$ & 1 & $1 \%$ & $0,1 \%$ & 8 & $1,3 \%$ & $0.1 \%$ \\
\hline & Élats corticaux $x>50 \%$ & 453 & $7,4 \%$ & $5.8 \%$ & 66 & $8,7 \%$ & $0,8 \%$ & 5 & $5 \%$ & $0,06 \%$ & 82 & $12,9 \%$ & $1,1 \%$ \\
\hline & Eclatta z cortex residuel $<50 \%$ & 1092 & $17,9 \%$ & $14,1 \%$ & 154 & 20.48 & 2.056 & 16 & $15 \%$ & $0,21 \%$ & 189 & $29,8 \%$ & $2.5 \%$ \\
\hline Eclats indifférenciés & Eclats sans cortex & 926 & $15,1 \%$ & 11,966 & 101 & $13,4 \%$ & $1,3 \%$ & 26 & $24 \%$ & $0.33 \%$ & 96 & $15,1 \%$ & $1.3 \%$ \\
\hline \multirow{3}{*}{$\begin{array}{l}\text { Produits predéterminants et } \\
\text { prédétermines }\end{array}$} & Éclats centréz & 446 & $7,3 \%$ & 5,786 & 50 & 6,656 & $0.6 \%$ & 2 & $2 \%$ & $=0.1 \%$ & 16 & $2.5 \%$ & $0.2 \%$ \\
\hline & Éclats débordants & 330 & $5,4 \%$ & $4.2 \%$ & 41 & $5,4 \%$ & $0.5 \%$ & 5 & $5 \%$ & $0.06 \%$ & 17 & $2.7 \%$ & $0.2 \%$ \\
\hline & Pointes preudo-Levallois & 220 & $3,6 \%$ & $2.8 \%$ & 24 & 3,26 & $0.3 \%$ & 10 & $9 \%$ & $0.13 \%$ & 14 & 2.28 & $0.2 \%$ \\
\hline \multicolumn{2}{|c|}{ Eclats Kombewa } & 121 & $2.0 \%$ & $1.6 \%$ & 29 & 3.85 & 0.486 & 3 & $3 \%$ & $\$ 0,1 \%$ & 1 & $0.2 \%$ & $20,1 \%$ \\
\hline \multicolumn{2}{|c|}{ Fragments } & $150 s$ & $24,7 \%$ & 19,48 & 136 & $18,0 \%$ & $1.8 \%$ & 29 & $27 \%$ & $0,37 \%$ & 93 & $14.7 \%$ & $1,2 \%$ \\
\hline \multirow{2}{*}{\multicolumn{2}{|c|}{ Eclats de retouche }} & 298 & $4.9 \%$ & $3,8 \%$ & 60 & $7,9 \%$ & $0.8 \%$ & 0 & & & 0 & & \\
\hline & & 185 & 3,06 & $2 A \%$ & 36 & $4.8 \%$ & $0.5 \%$ & 4 & $4 \%$ & $0,05 \%$ & 33 & $5,2 \%$ & $0.4 \%$ \\
\hline \multicolumn{2}{|c|}{$\begin{array}{l}\text { Nudeus } \\
\text { Cassons }\end{array}$} & 363 & $5,9 \%$ & 4.786 & 14 & $1,96 \%$ & $>0.1 \%$ & 3 & $3 \%$ & $=0.16$ & 62 & $9,8 \%$ & $0,8 \%$ \\
\hline \multirow{2}{*}{\multicolumn{2}{|c|}{ Indétermines }} & 10 & $0.2 \%$ & $0.1 \%$ & & & & 3 & 376 & $>0,1 \%$ & 23 & $3.6 \%$ & $0.3 \%$ \\
\hline & & 6114 & $100 \%$ & $78,7 \%$ & 755 & $100 \% 6$ & $9,7 \%$ & 107 & $100 \% 6$ & $1,4 \%$ & 634 & $100 \%$ & $8,3 \%$ \\
\hline
\end{tabular}

\section{2 - Techno-economic analysis}

\subsection{1 - General technological characteristics}

19 The industry is distinctive in that extremely homogeneous methods are employed for the different blanks, with no differentiation between raw materials. In this way, almost all of the series is related to the Discoid debitage method (Turq 1992; Boëda 1993; Jaubert 1993, 1994; Locht and Swinnen 1994; Slimak 1999, 2003; Brenet and Folgado 2003; Mourre 2003; Peresani (dir.) 2003).

Flake butts are mostly smooth and generally wide and thick with very marked bulbs and impact points, which tends to denote the predominant or even exclusive use of direct percussion techniques with a hard hammer. This correlates well with the presence of knapped and non-knapped, mostly fractured quartzite pebbles ( $\mathrm{n}=14$, or $2.2 \%)$, with percussion marks on the outer pebble surface.

21 A little less than $10 \%$ of the produced blanks are then worked with a hard hammer and a receding motion, in an alternating sequence, to produce notches and denticulates.

\subsection{2 - Debitage and production methods}

\section{Debitage blanks}

Blocks ( $n=80$, or $31 \%$ of the cores), flakes $(n=137$, or $53 \%)$ or pebbles $(n=32$ or $40 \%)$ were used for knapping. Cores were differentiated depending on the number of knapped surfaces, then the methods used for their exploitation, which can consist in the extraction of one or two flakes, or which can be more complex. In the absence of refits, our observations are based on final core morphology, which enables us to visualize the last knapped sequence. 


\section{The cores}

Two main types of flint cores stand out:

- on one hand, core production on cortical flakes of average dimensions, following unipolar, bipolar and convergent methods on one or two surfaces, with a strong degree of flattening ( $\mathrm{n}=85$, or $32 \%$ of the cores) (fig. $4, \mathrm{n}^{\circ} 2$ and 4 );

- on the other hand, cores on blocks were completely decorticated following a centripetal sequence ( $n=43$ or $16 \%$ ). These cores are significantly reduced and well maintained, with a tendency to become globular in shape (fig. 4, $\mathrm{n}^{\circ} 1$ and 3).

The cores in Senonian flint are more intensively exploited than those in Tertiary chalcedony, and are smaller in size with increased productivity. The metaquartzite cores are mainly characterized by unifacial knapping on large pebbles; they are typical of discoid cores in quartz and quartzite (Jaubert et al. 1990; Jaubert 1994; Mourre 1996; Jaubert and Mourre 1996), with a neocortical reserve on the surface opposite the knapped surface, and a pyramidal section.

They are characteristic of the discoid series in quartz and quartzite already documented in the region (e.g. La Borde: Jaubert et al. 1990; Mauran: Jaubert 1994; layer G7 of Les Fieux: Faivre 2004; Coudoulous 1 c4: Mourre 1994; Les Bosses: Jarry et al. 2007; Faivre et al. 2013) (fig. 5).

Figure 4 - Roc de Combe (Lot), Discoid-Denticulate Mousterian. Discoid cores on blocks and flakecores. 1: Discoid Senonian flint core on block reduced following a centripetal sequence. 2: Senonian flint cortical bifacial flake-core reduced following a unipolar sequence. 3: bi-pyramidal core on block in Tertiary chalcedony. 4: Flake-core in Tertiary chalcedony knapped by a centripetal sequence. Credits: MNP Les Eyzies - Dist. RMN- photo Ph. Jugie.
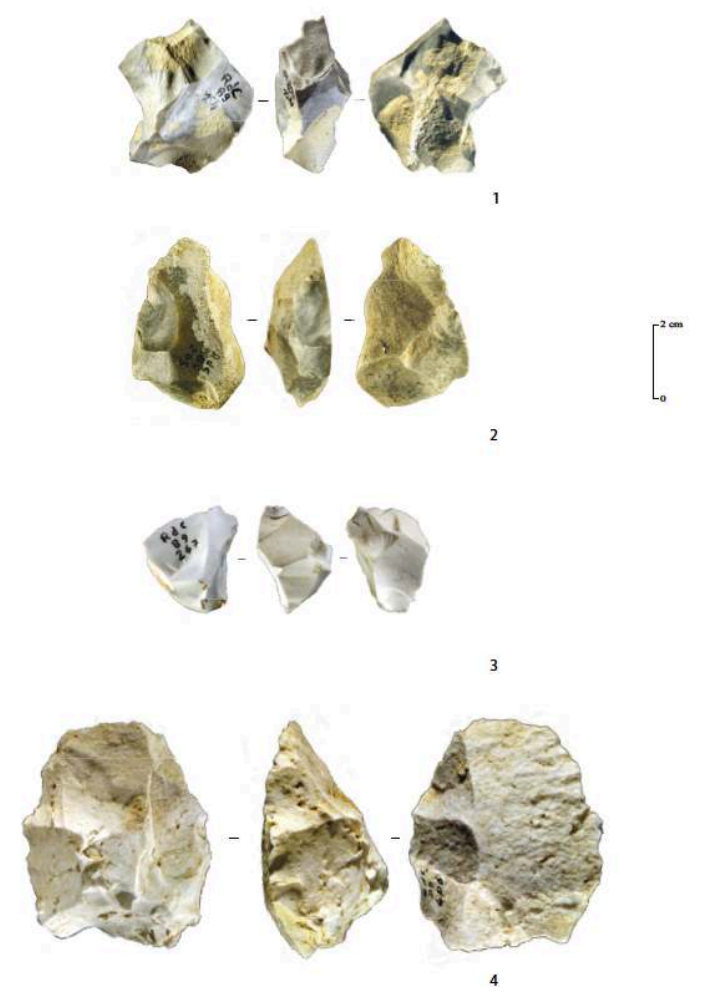

PALEO, 25 | 2014 
Figure 5 - Roc de Combe (Lot), Denticulate-Discoid Mousterian. Quartzite cores. 1: bifacial Discoid core. 2: unifacial Discoid core. Credits: MNP Les Eyzies - Dist. RMN- photo Ph. Jugie.

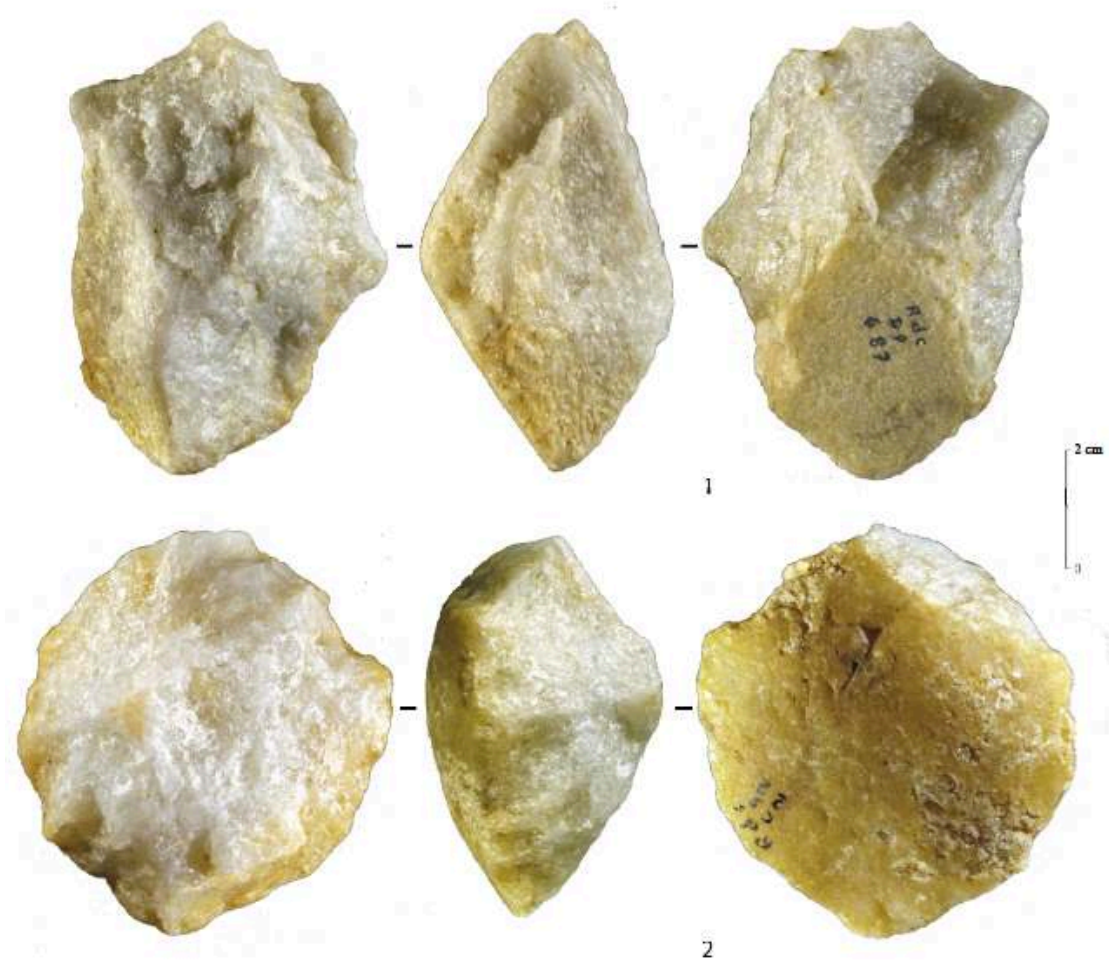

\section{Products}

Most of the products obtained are non-differentiated, cortical or non-cortical flakes, as well as typical Discoid debitage flakes, such as pseudo-Levallois points, débordant flakes and centred flakes (Bordes 1961; Boëda, Geneste, Meignen 1990; Boëda 1993, 1995; Meignen 1993; Bourguignon and Turq 2003; Mourre 2003; Slimak 2003; Faivre 2008) (tab. 1 and fig. 6 and 7). We distinguished on one hand, long centred flakes and invasive débordant flakes which level out convexities and, on the other, pseudoLevallois points and short centred flakes, which accentuate convexities. Knapping followed a secant angulation and a centripetal direction (centred flakes) or "chordal" direction (débordant flakes lato sensu). A degree of standardization is evident in the asymmetrical blanks, whether they present a back opposite the cutting edge or a thick butt with a cutting edge along the perimeter. These flakes are grouped together in the "predetermining and predetermined flake" category (Boëda 1993) as they take on the ambivalent role of both the purpose of production and/or self-maintaining core preparation. The low proportion of this type of product in comparison to other series could be explained by the exportation of these pieces (tab. 2 and fig. 8). The proportions of these pieces and cross-checking with other regional series show that these products indicate knapping intentionality. 
Figure 6 - Roc de Combe (Lot), Denticulate-Discoid Mousterian. 1: Typical pseudo-Levallois point in Cenozoic chalcedony. 2 and 3: atypical pseudo-Levallois points in Cenozoic chalcedony. 4: Typical pseudo-Levallois point in Senonian flint. Credits: MNP Les Eyzies - Dist. RMN- photo Ph. Jugie.
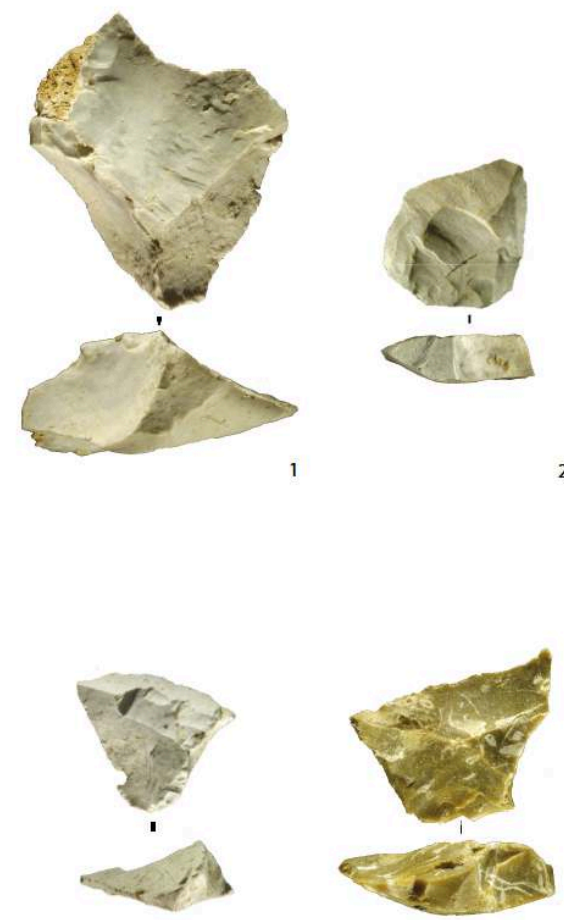

Figure 7 - Roc de Combe (Lot), Flint industry in Cenozoic chalcedony. 1, 2, 3 and 6: pseudo-Levallois points. 4 and 5: atypical pseudo-Levallois points. 7 and 8: centripetal debordant flakes. Drawings: G. Devilder.
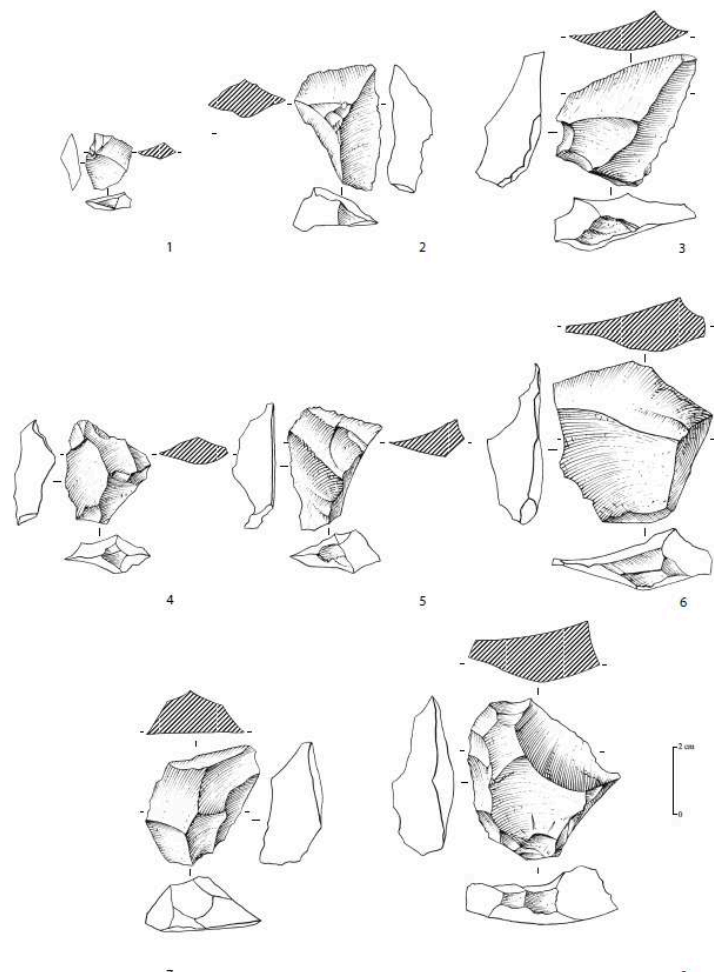
Table 2 - Comparison of proportions of predetermining and predetermined flakes in relation to blanks included in the "stricto sensu" Discoid sites (when data are available).

\begin{tabular}{|c|c|c|c|c|c|c|c|c|}
\hline Sites & $\begin{array}{l}\text { Pointes } \\
\text { pseudo- } \\
\text { Levallois }\end{array}$ & $\%$ & $\begin{array}{c}\text { Éclats } \\
\text { débordants }\end{array}$ & $\%$ & $\begin{array}{l}\text { Éclats } \\
\text { centrés }\end{array}$ & $\%$ & $\begin{array}{c}\text { Total produits } \\
\text { (MP } \\
\text { dominante) }\end{array}$ & Bibliographie \\
\hline $\begin{array}{l}\text { SAINT } \\
\text { CÉSAIRE }\end{array}$ & 299 & $7 \%$ & 465 & $11 \%$ & 114 & $3 \%$ & 4170 & Thiébaut 2005 \\
\hline MAURAN & 56 & $7 \%$ & - & - & - & - & 763 & Jaubert 1994 \\
\hline $\begin{array}{l}\text { BEAUVAIS } \\
\text { NIV.1 }\end{array}$ & & 126 & & $7 \%$ & 110 & $6 \%$ & 1780 & Locht 2004 \\
\hline $\begin{array}{l}\text { BEAUVAIS } \\
\text { NIV. } 2\end{array}$ & 348 & $4 \%$ & 208 & $2 \%$ & 331 & $3 \%$ & 9879 & Locht 2004 \\
\hline $\begin{array}{l}\text { CHAMPS DE } \\
\text { BOSSUET }\end{array}$ & 926 & $8 \%$ & 1841 & $16 \%$ & - & - & 11359 & $\begin{array}{c}\text { Bourguignon Turq } \\
2003\end{array}$ \\
\hline $\begin{array}{c}\text { COMBE } \\
\text { GRENALC } \\
11\end{array}$ & & 120 & & $B \%$ & $=$ & - & 1499 & Thiébaut 2005 \\
\hline $\begin{array}{c}\text { COMBE } \\
\text { GRENALC } \\
14\end{array}$ & 174 & $6 \%$ & 543 & $19 \%$ & - & - & 2884 & $\begin{array}{c}\text { Bourguignon Turq } \\
2003\end{array}$ \\
\hline $\begin{array}{c}\text { COMBE } \\
\text { GRENALC } \\
12\end{array}$ & 148 & $18 \%$ & 143 & $17 \%$ & 98 & $12 \%$ & 838 & Faivre 2008 \\
\hline $\begin{array}{l}\text { LES FIEUX } \\
\text { G7 }\end{array}$ & 60 & $10 \%$ & 45 & $8 \%$ & 47 & $8 \%$ & 585 & Faivre 2002 \\
\hline LES FIEUXIJ. & 256 & $28 \%$ & 112 & $12 \%$ & 148 & 1696 & 900 & Faivre 2008 \\
\hline $\begin{array}{c}\text { LES } \\
\text { ROCHERS S }\end{array}$ & 17 & $7 \%$ & 5 & $2 \%$ & 11 & $4 \%$ & 258 & Asselin 2005 \\
\hline $\begin{array}{l}\text { LES } \\
\text { ROCHERS N }\end{array}$ & 28 & $27 \%$ & 26 & $25 \%$ & 37 & $36 \%$ & 103 & Asselin 2006 \\
\hline
\end{tabular}

Figure 8 - Proportion of predetermining and predetermined blanks and distribution of "stricto sensu" Discoid sites.

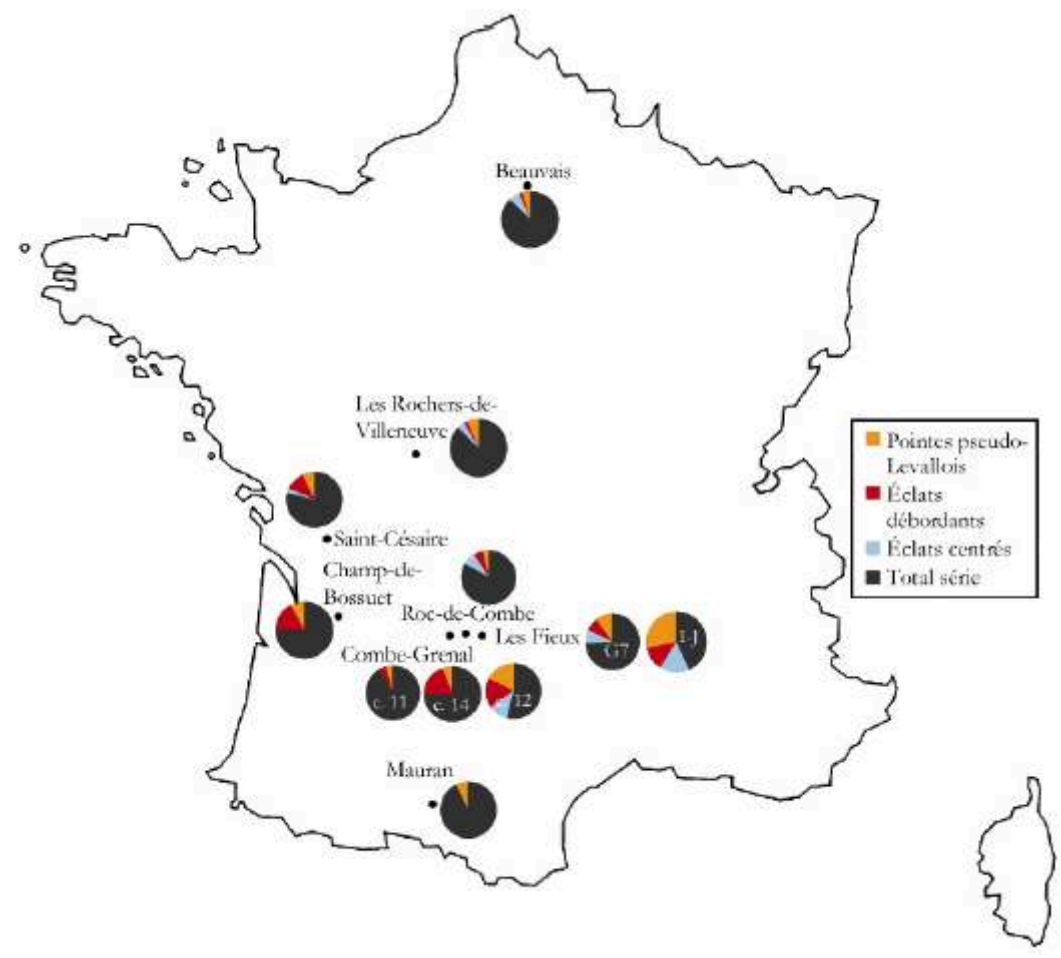


This hypothesis is backed up by the analysis of the last removal scar on the cores, showing that the proportions of non-differentiated non-cortical flakes and predetermining and predetermined flakes are almost equivalent (44\% and $56 \%$ respectively). However, these results are not the same for Senonian flint, which presents a higher proportion of predetermining and predetermined flakes.

\subsection{3 - Management of debitage products and typological composition of the retouched tools}

\section{Transformed blanks}

The product transformation rate is rather low $(6.78 \%$ of products, all technological categories included, apart from fragments) (fig. 9). However, this rate conceals important differences for each raw material (tab. 3). Retouched blanks in Tertiary chalcedony only represent $7.1 \%$ of the blanks in this raw material, whereas retouched tools account for $16.9 \%$ of the blanks in Senonian flint. As is often the case, the quartzites/metaquartzites present the lowest rate of retouch $(2.3 \%)$. For the other types of flint, 15 pieces are retouched, representing an average proportion (7.4\%).

There are also differences in the choice of type of transformed blanks (tab. 3): for Tertiary chalcedony, cortical flakes present a high rate of retouch $(22.9 \%$ of all the retouched pieces), as do flake fragments (19\%), but proportionally, debordant flakes lato sensu $(26.8 \%)$ and Kombewa-type flakes $(9.9 \%)$ present the highest rate of retouch. Generally, retouched pieces display smaller dimensions than non-retouched blanks.

For Senonian flint, the most retouched blanks are clearly flakes with cortical residue (40.4\%). Cortical flakes (cortex $<50 \%$ and $>50 \%$ ) and Kombewa type flakes were preferentially transformed within each category. Predetermining and predetermined flakes present lower rates of retouch. The largest blanks were selected for retouch in each category, apart from the mostly cortical flakes, pseudo-Levallois points and flake fragments.

Retouched blanks in quartzite are exclusively flakes with a natural pebble surface or a natural back, where a lateral edge was preferentially transformed.

\section{Typology}

Denticulates make up by far the largest category $(n=257)$, with $49.8 \%$ of the retouched blanks (tab. 4 and fig. 10, $n^{\circ} 1,2,3,4,5$ and 8), in all raw materials, followed by notches $(n=102)$ or $19.7 \%$. Blanks in Senonian flint bear more denticulate retouch than the other raw materials: $57 \%$ as opposed to $45 \%$ for flakes in Tertiary chalcedony and $40 \%$ for quartzites. Microdenticulates (sensu Thiébaut 2005) (fig. 10, $\mathrm{n}^{\circ} 3$ and 5) are dominant among denticulate tools (69\%), followed by denticulates with average-sized denticulation (21\%) (fig. 10, $\mathrm{n}^{\circ} 4$ and 8), and lastly by macro-denticulates (8 \%) (fig. 10, $n^{\circ} 4$ ]. Denticulations are often opposed to a thick base or a back $(n=72$, or $14 \%$ of the tools) (fig. 10, $\mathrm{n}^{\circ} 4,5$ and 8]. This edge could have been used as a prehensile or gripping zone, opposite the active edge. Several blanks bear convergent denticulated retouch on the distal edges ( $\mathrm{n}=11$ or $2.1 \%$ of the tools), assimilating them to Tayac points. Unlike for the denticulated pieces, macro-notches dominate the notched tools (notches of up to $3 \mathrm{~cm}$ ) (fig. 10, $\mathrm{n}^{\circ} 7$ ). 
scrapers represent a small proportion of the tools $(n=24)$, or only $4.7 \%$ of retouched tools, with considerable differences from one raw material to another. There are no side scrapers in quartzite, but they make up $6 \%$ of the Senonian retouched blanks and $5 \%$ of the Tertiary materials. Side scrapers were mostly made on pseudoLevallois points $(29.4 \%)$ and debordant flakes $(23.5 \%)$, by short retouch on the edge opposite the back, with a predominance of simple concave side scrapers. The side scrapers in Senonian flint are mainly simple, straight, convex or concave. Other types of retouched tools were also observed, such as composite tools (fig. 10, $\mathrm{n}^{\circ} 6$ ) or pieces with partial, non-classifiable or atypical retouch (tab. 4).

\section{Several discordant pieces}

This homogeneous techno-typological series, with near exclusive Discoid debitage, dominated by denticulates and notches, contains five rather discordant pieces ( $0.9 \%$ of the tools). They are part of the recent Palaeolithic typology from the overlying Chatelperronian levels (cf. discussion in Bordes 2002 - p. 68 and ss.) and are made up of: an end scraper, a distal fragment of a small blade, a mesial part of a backed piece and a lamellar flake with an obverse facet, probably from making a busqué burin. These elements are from the extreme top of the excavated zone, in an area where the levels were not well characterized, according to the excavators, and were partly made up of collapsed spoil from the Labrot excavations, particularly in the Chatelperronian levels. It is thus clear that they derive from vertical migrations.

\section{Retouch flakes}

The series consists of 355 small flint flakes with a thin section, a straight upper surface and a generally convex lower surface (fig. 11). The morphology and dimensions of these pieces relate them to retouch flakes and several types have been defined based on published examples (Bourguignon 1997; Faivre 2008). The morpho-technical diversity denotes different stages and techniques of blank transformation. Notch flakes are predominant (38 \%) (fig. 11, $\mathrm{n}^{\circ} 1$ and 2), followed by notch resharpening flakes (33\%) (fig. $11 \mathrm{n}^{\circ} 3$ ), then by resharpening flakes from indeterminate tools (14\%). As evidence of resharpening on the tools themselves is low, this high percentage of resharpening flakes, particularly from notches, is particularly noteworthy. However, as small objects were not systematically collected during excavations, it is difficult to interpret these proportions. 
Figure 9 - Roc de Combe (Lot), Discoid-denticulate Mousterian. Proportion of retouched and nonretouched blanks by blank category, all raw materials combined.

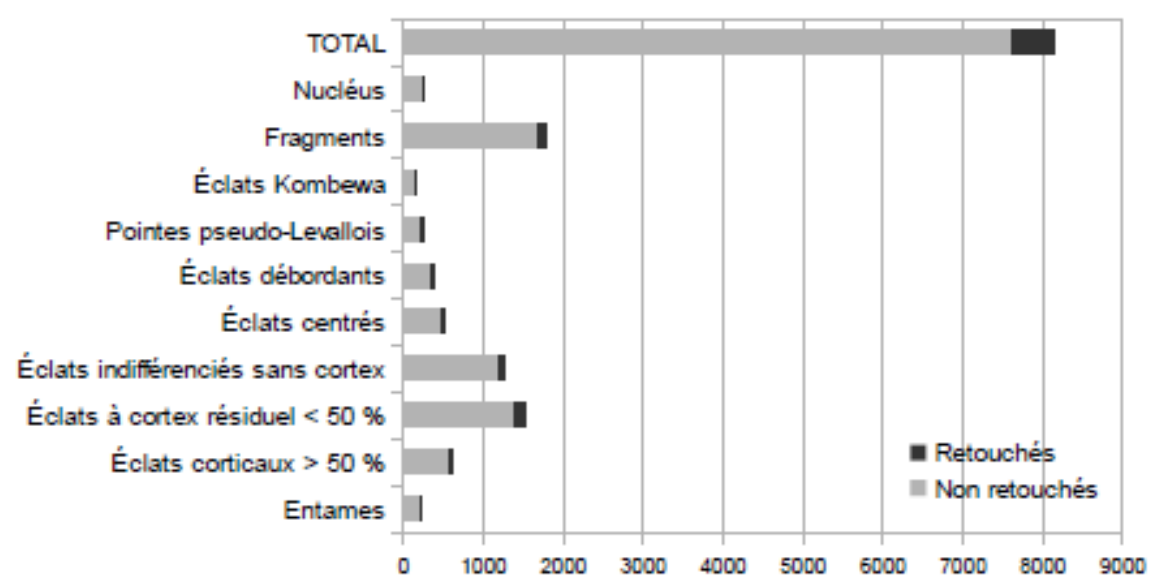

Table 3 - Roc de Combe (Lot), Number of retouched and unretouched blanks by blank category and lithic raw material.

\begin{tabular}{|c|c|c|c|c|c|c|c|c|}
\hline \multirow{2}{*}{ Supports } & \multicolumn{2}{|c|}{ Calcédoine tertiaire } & \multicolumn{2}{|c|}{ Silex sénonien } & \multicolumn{2}{|c|}{ Quartzites } & \multicolumn{2}{|c|}{ Autres MPL } \\
\hline & Ret. & Non ret. & Ret. & Non ret. & Ret. & Non ret. & Ret. & Non ret. \\
\hline Entames & 7 & 155 & 0 & 44 & 0 & 8 & 0 & 1 \\
\hline Éclats corticaux $>50 \%$ & 29 & 424 & 14 & 52 & 6 & 76 & 0 & 5 \\
\hline Éclats à cortex résiduel $<50 \%$ & 88 & 1004 & 44 & 110 & 6 & 183 & 2 & 12 \\
\hline $\begin{array}{l}\text { Éclats indifférenciés sans } \\
\text { cortex }\end{array}$ & 57 & 869 & 9 & 92 & 0 & 96 & 3 & 23 \\
\hline Éclats centrés & 39 & 407 & 8 & 42 & 0 & 16 & 0 & 1 \\
\hline Éclats débordants & 45 & 285 & 4 & 37 & 0 & 17 & 0 & 5 \\
\hline Pointes pseudo-Levallois & 29 & 191 & 4 & 20 & 0 & 14 & 2 & 1 \\
\hline Éclats Kombewa & 12 & 109 & 8 & 21 & 0 & 1 & 0 & 2 \\
\hline Fragments & 73 & 1435 & 18 & 118 & 0 & 93 & 1 & 27 \\
\hline Nucléus & 5 & 180 & 0 & 36 & 0 & 33 & 0 & 4 \\
\hline TOTAL & 384 & 5059 & 109 & 572 & 12 & 537 & 8 & 81 \\
\hline
\end{tabular}

\section{4 - Discussion}

\section{1 - General evaluation}

Discoid debitage is the only knapping method used at Roc de Combe, and is oriented towards the extraction of asymmetrical blanks with thick edges. It is similar to series such as Beauvais, Oise (Locht 2004), Champs de Bossuet (A89, Gironde) and CombeGrenal, Dordogne, c. 13-15 (Bourguignon and Turq 2003), Les Fieux, Lot, c. G7 and I- J (Faivre 2008), Mauran, Haute-Garonne (Jaubert 1994), Saint-Césaire, CharenteMaritime, Egf-10-11 (Thiébaut, Meignen, Lévêque 2009), La Quina, Charente, c. 5-Gc (Park 2007) or les Rochers de Villeneuve, Vienne, c.N (Asselin 2005). However, on account of the limited technological variability (centripetal and similar debitage systems are predominant), the Roc de Combe group is part of the Mousterian Discoid debitage group stricto sensu defined by V. Mourre (Mourre 2003). Due to the predominance of denticulates and the very low proportion of side scrapers $(<5 \%)$, this series can be included in complex 1, defined by C. Thiébaut, regrouping the Discoiddenticulate Mousterian levels of diverse sites attributed to OIS 3 with monospecific faunal exploitation (Thiébaut 2005). 


\section{2 - Comparative study}

Several points need to be expanded upon in order to situate the Roc de Combe Mousterian in its regional context, on one hand, and in current debates on technocomplexes from the Late Middle Palaeolithic (LMP), on the other.

Figure 10 - Roc de Combe (Lot), Discoid-denticulate Mousterian. 1 to 5: tool group in Cenozoic chalcedony. 1 and 2: medium-sized denticulation on pseudo-Levallois points. 3: microdenticulate cortical backed flake. 5: microdenticulate débordant flake. 6 to 8: Senonian flint tool group. 6 : mixed tools (scraper and denticulate). 7: Clactonian macro-notched cortical backed flake. 8: medium-sized denticulation and microdenticulation debordant flake. Credits: MNP Les Eyzies Dist. RMN- photo Ph. Jugie.

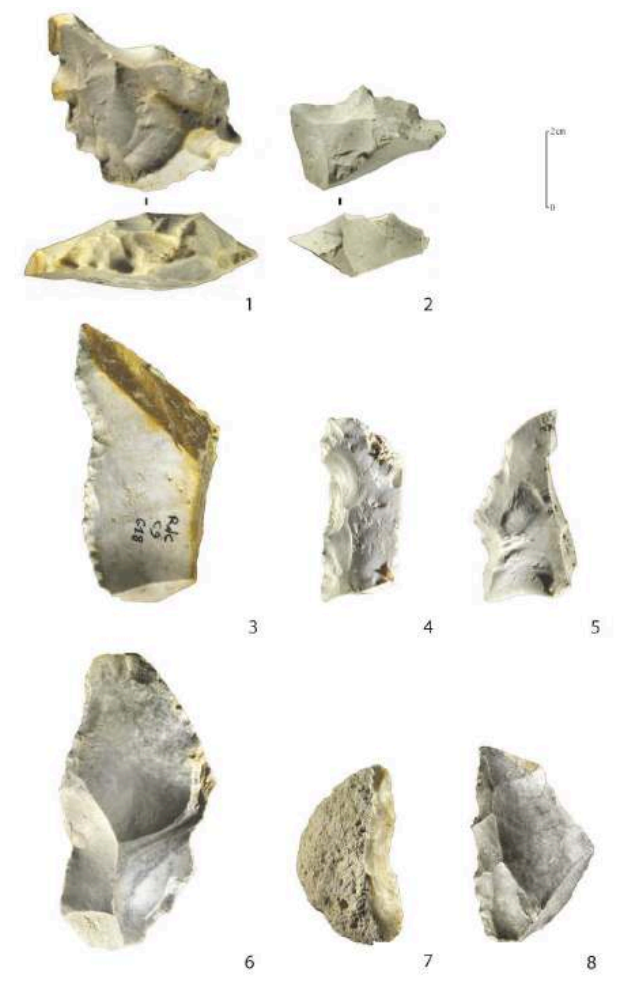

The morphotechnical diversity of the blanks obtained at the end of the sequence, for both cores and derived products, denotes a rather variable Discoid debitage. Several recent studies show that the Discoid concept governs several debitage methods and different structures of the operative sequence (Mourre 2003; Slimak 2003; Bourguignon, Faivre, Turq 2004; Locht 2004; Faivre 2008). Debitage sequences are short or long and involve different methods, which are not exclusively centripetal (uni or bifacial), according to the classical definition (Boëda, Geneste, Meignen 1990; Boëda 1993; Meignen 1993). The presence of different types of blanks linked to the different raw materials used raises the question of the structure of the operative sequence. Several structures have been described for the Middle Palaeolithic, and the three main ones (summarized in Delagnes 2010) are ramification, recycling and "scalar structure" (Geneste 1991; Bourguignon, Faivre, Turq 2004). It is important to evaluate the final debitage aims and their morpho-technical characteristics, as well as the methods used for each operative sequence, as they indicate a debitage economy and different degrees of anticipation. At Roc de Combe, the Discoid method is the sole method, regardless of 
the different flints and quartzites used, with standardized systems and techniques, like at Mauran (Jaubert 1994). The notion of differential debitage economy - which entails differential raw material management (Perlès 1991) - cannot be retained here.

Table 4 - Roc de Combe (Lot). Number and proportion of different retouch types by raw material.

\begin{tabular}{|c|c|c|c|c|c|c|c|c|c|c|}
\hline \multirow{2}{*}{ Outils } & \multicolumn{2}{|c|}{ Calcédoine tertiaire } & \multicolumn{2}{|c|}{ Silex sénonien } & \multicolumn{2}{|c|}{ Quartzites } & \multicolumn{2}{|c|}{ Autres MPL } & \multirow{2}{*}{$\begin{array}{l}\text { Total par } \\
\text { type de } \\
\text { retouche }\end{array}$} & \multirow[t]{2}{*}{$\%$} \\
\hline & Effectif & $\%$ & Effectif & $\%$ & Effectif & $\%$ & Effectif & $\%$ & & \\
\hline DENTICULÉS & 175 & $47,4 \%$ & 72 & $57,6 \%$ & 6 & $60,0 \%$ & 4 & $40,0 \%$ & 257 & $50,0 \%$ \\
\hline ENCOCHES & 79 & $21,4 \%$ & 18 & $14,4 \%$ & 3 & $30,0 \%$ & 2 & $20,0 \%$ & 102 & $19,8 \%$ \\
\hline DENT repris & 2 & $0,5 \%$ & & & & & & & 2 & $0,4 \%$ \\
\hline ENC repris & 1 & $0,3 \%$ & & & & & & & 1 & $0,2 \%$ \\
\hline RACLOIRS & 17 & $4,6 \%$ & 6 & $4,8 \%$ & & & 1 & $10,0 \%$ & 24 & $4,7 \%$ \\
\hline MIXTES & 29 & $7,9 \%$ & 10 & $8,0 \%$ & & & 3 & $30,0 \%$ & 42 & $8,2 \%$ \\
\hline $\begin{array}{l}\text { FRAGMENT } \\
\text { D'OUTIL }\end{array}$ & 13 & $3,5 \%$ & 2 & $1,6 \%$ & 1 & $10,0 \%$ & & & 16 & $3,1 \%$ \\
\hline $\begin{array}{l}\text { RETOUCHE } \\
\text { PARTIELLEE }\end{array}$ & 12 & $3,3 \%$ & 5 & $4,0 \%$ & & & & & 17 & $3,3 \%$ \\
\hline NON TYPABLE & 10 & $2,7 \%$ & 1 & $0,8 \%$ & & & & & 11 & $2,1 \%$ \\
\hline $\begin{array}{l}\text { QUELQUES } \\
\text { RETOUCHES }\end{array}$ & 29 & $7,9 \%$ & 4 & $3,2 \%$ & & & & & 33 & $6,4 \%$ \\
\hline RETOUCHE? & 2 & $0,5 \%$ & 7 & $5,6 \%$ & & & & & 9 & $1,8 \%$ \\
\hline TOTAL & 369 & $100 \%$ & 125 & $100 \%$ & 10 & $100 \%$ & 10 & $100 \%$ & 514 & $100 \%$ \\
\hline
\end{tabular}

Figure 11 - Roc de Combe (Lot), Denticulate Discoïd Mousterian. Different types of notched flakes. 1: non-cortical notched flake. 2: notched flake from the inferior surface flake. 3: re-sharpening flake from a non-cortical notch. 4: re-sharpening flake from a denticulate. Drawings: G. Devilder.

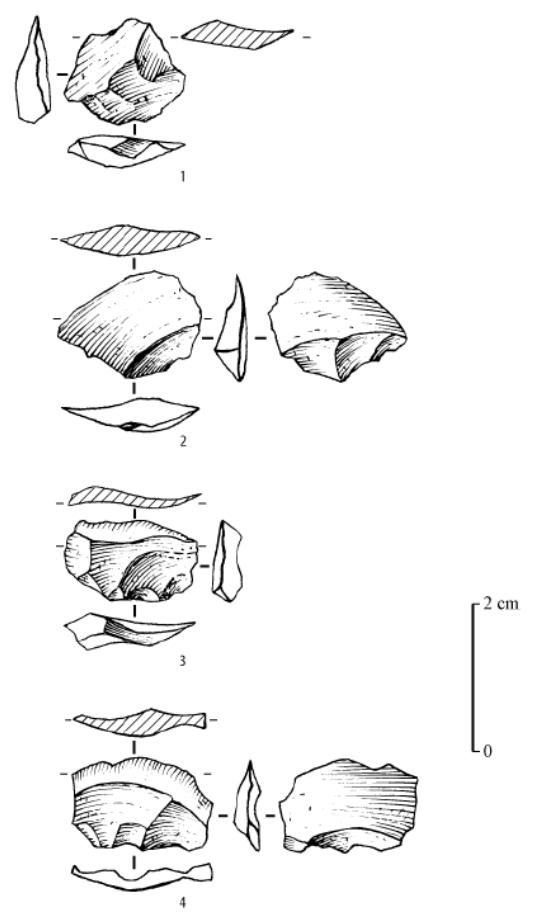

However, note that some differences exist, for example in the length of the sequences and final debitage aims: the cores in Senonian flint show optimal management, for example, with more carefully made hinges and convexities, and debitage generally comes to an end due to reduced core size. Blanks are preferentially cortical flakes and they may have been imported for debitage. The analysis of the products does not show 
strong morpho-technical differentiation linked to core type: final debitage aims are identical for the different types of cores and raw materials. Blocks and flakes extracted from these blocks are exploited using the Discoid method, in order to produce cortical flakes (used as tools or as cores), as well as predetermined and predetermining flakes. This results in a reduction of dimensions during production, for similar blanks. The principle of recurrence over different generations of products (Geneste 1991) is applied, or "diminutive and proportional recurrence of production" (Delagnes 2010). This principle is applied until its limits, as shown by the cores transformed into denticulates $(n=5)$. In the same way, notched tools raise the question of a microdebitage, recorded for example at Champs de Bossuet and Combe-Grenal (Bourguignon and Turq 2003; Bourguignon, Faivre, Turq 2004).

\section{3 - Dates}

40 Several radiocarbon dates were obtained in the 1990s for the Upper Palaeolithic sequence of Roc de Combe (Hedges et al. 1990). A lot of the inconsistencies in the dates can be explained by the mixing of material brought to light during the taphonomic analysis of the lithic industries (Bordes 2002, p. 95). Others are linked to the modification of layer labels between the excavation and publication (ibidem). Given this context, new dating attempts were made on material from squares and layers where interstratification was observed. This work was carried out in 2002 by $\mathrm{H}$. Valladas, as part of the Eclipse project (coord. M.-F. Sánchez Goñi).

41 The dated pieces are unburnt bones, with square and layer references. They enabled us to confirm the existence of mixed levels in this zone of the site (tab. 5).

42 Given the archaeological context of the dated objects, it is very probable that some of these results relate to Mousterian occupations (tab. 5). The oldest of these dates is around 45-50 ka BP, confirming that this Discoid denticulate Mousterian from Roc de Combe is very recent. This result is in agreement with the typo-technological characteristics of the series and the ages obtained for other similar techno-complexes in south-western France (summarized in Guibert et al. 2008).

\section{4 - Techno-economic overview: the regional context of the Mousterian from Roc-de-Combe}

Acquisition is predominantly local with $97.8 \%$ of the raw materials from a distance of less than $10 \mathrm{~km}$ from the site: Tertiary chalcedony, Senonian flint, quartzites, etc. A minute proportion of the lithic materials $(0.05 \%)$ come from more than $40 \mathrm{~km}$ from Roc de Combe, and up to $70 \mathrm{~km}$ away (Bergeracois and Fumélois flint). A comparison with neighbouring Quercy sites; Les Fieux, layers G7 and K and La Borde and Combe-Grenal, in Périgord, layers 12 and 20, where a Mousterian industry with denticulates was identified (Bordes 1972; Jaubert et al. 1990; Faivre 2002, 2006, 2008; Thiébaut 2005; Faivre et al. 2013) shows that the presence of exotic raw materials, such as Fumélois, had never been observed up until now. At the Fieux site, raw material procurement is local or regional $(<12 \mathrm{~km}$ for layer $\mathrm{K}$ and $<25-30 \mathrm{~km}$ for layer $\mathrm{G}$, which contains these haut-Agenais flints: Turq 1992, 2000) due to the distances of outcrops and an atypical circuit. However, the published sites are mostly in the Quercy region (Chalard et al. 
2007), which would appear to give Roc-de-Combe a particular status in the region, between Dordogne and Quercy?

Table 5 - Roc de Combe (Lot). $14 \mathrm{C}$ data. Dates by H. Valladas, in collaboration with F. d'Errico, as part of the Excursion program Eclipse project (coord. M.-F. Sánchez-Goñi). The dated objects are unburnt bones, marked with the name of the square and layer.

\begin{tabular}{|c|c|c|c|c|}
\hline $\begin{array}{l}\text { Nom du } \\
\text { carré / déc }\end{array}$ & $\begin{array}{l}\text { Couche } \\
\text { d'après } \\
\text { sachets }\end{array}$ & $\begin{array}{l}\text { Nom de la } \\
\text { date }\end{array}$ & Âge BP & Contenu après tapho \\
\hline $\mathrm{H} 10$ & 10 & OxA 1264 & $31000 \pm 750$ & \multirow{2}{*}{$\begin{array}{l}\text { Moustérien + qq } \\
\text { éléments du PS }\end{array}$} \\
\hline $\mathrm{H} 10$ & 10 & OxA 1443 & $38000 \pm 2000$ & \\
\hline G8 & 1a & OxA 1254 & $32000 \pm 1000$ & $\begin{array}{l}\text { Mélange généralisé, du } \\
\text { Gravettien au } \\
\text { Moustérien }\end{array}$ \\
\hline G10 & B.1 & GifA 101261 & $50000 \pm 2400$ & \multirow{3}{*}{$\begin{array}{l}\text { Mélange généralisé de } \\
\text { Aurignacien, } \\
\text { Châtelperronien, } \\
\text { Moustérien }\end{array}$} \\
\hline G10 & B.1 & GifA 101262 & $44700 \pm 2900$ & \\
\hline F8 & $\mathrm{C}$ & GifA 101263 & $35210 \pm 550 . \mathrm{BP}$ & \\
\hline K9 & 8 & GifA 101264 & $39540 \pm 970$ & \multirow{3}{*}{$\begin{array}{l}\text { Châtelperronien avec } \\
\text { Moustérien Levallois à } \\
\text { la base }\end{array}$} \\
\hline K9 & 8 & GifA 101265 & $45100 \pm 2100$ & \\
\hline K9 & 8 & GifA 101266 & $40000 \pm 1300$ & \\
\hline
\end{tabular}

The Combe-Grenal sites also show local procurement strategies $(<12 \mathrm{~km})$ and the raw material provisioning territory of La Borde, which is chronologically older and geographically further away, extends to about $40 \mathrm{~km}$. Several authors suggest the circulation of material (whereby Mousterians would carry a stock of raw material with them, to be used and abandoned during their movements) (Turq 1992, 2000; Faivre et al. 2013) from west to east, from Perigord towards Quercy and vice versa in very small proportions. This could coincide with large mammal seasonal movements (Chalard et al. 2007; Turq and Morala op. cit.). No procurement from the haut-Agenais towards the Quercy Causses has been identified up until now. Therefore, apart from Combe-Grenal, Roc-de-Combe appears to stand out from other regional sites.

Core exploitation does not require an elaborate preparation phase (or cortex removal) as convexities are rapidly obtained with Discoid debitage, providing ideal surfaces for the production of different types of products, with probable overlap between strict initialization and production phases. These two phases also merge for quartzite pebbles: the physical properties of the natural pebble surface provide optimal striking platforms, as shown some time ago (Tavoso 1978). The natural convexities of local raw materials or rapidly prepared convexities lead to the concomitance of these two phases, which serve at least two purposes: production of large cortical flakes to be used as tools (as they are or retouched) and the production of similar flakes to be used for a second production phase.

The deficit of some categories of blanks (Kombewa type flakes and pseudo-Levallois points for the dominant raw materials) shows a preferential exportation strategy. They represent products intended for exportation. The characteristics of the lesser represented flint industry show that diverse raw materials passed through Roc-deCombe. These materials are rare and from distant sources and are an easily identifiable marker of movements. This is not the case for the industries in the dominant raw 
materials, which may have been transported over short (or longer) distances, but do not leave any evidence of these movements.

Recycling can also be considered on account of the presence of a series of pieces with a double patina $(\mathrm{n}=27)$, which were abandoned and subsequently reused.

The figures show that all the sequences of the chaîne opératoire (Geneste 1985) are recorded in situ, from cortex removal until the abandonment stage. However, caution must be applied as this could dissimulate more complex behaviour, i.e., the importation of blanks knapped elsewhere, then transported. The diversity of the physical characteristics of the pieces themselves, as well as the classic counts, is thus an essential criterion for the reconstruction of the operative sequence.

\section{Conclusion and perspectives}

The local geological setting of the Bouriane, which contains less high quality raw materials than the neighbouring Perigord region (Sarladais, black Périgord), did not prevent Mousterians from procuring most of their raw materials there. They opted for a debitage concept that could be reproduced on all types of materials (Senonian or Tertiary flint, quartz/metaquartzites). This denotes an adaptive capacity, high mobility, perhaps within a rather limited, and difficult to define territory (not perceptible solely through lithic raw materials) (Faivre 2002; Delagnes 2010; Delagnes and Rendu 2011). On account of this, debitage sequences are indifferently short or long, regardless of raw material provisioning. Production is oriented towards blanks with a relatively standardized morphology, made up of flakes with an asymmetrical section and profile with a back opposite the cutting edge, as well as cortical flakes. This type of production sequence does not require the use of excellent quality raw materials. Several pieces from distant sources provide evidence of movement or the occasional exchange of objects up to a distance of about $70 \mathrm{~km}$.

This Roc de Combe series joins the list of Middle Palaeolithic sites with Discoid debitage and denticulated tools, chronologically positioned near the end of the Late Middle Palaeolithic in the southwest of France (Thiébaut 2005; Jaubert et al. 2011; Jaubert 2012). These sites are all more recent than the MTA, as it is generally regionally defined (Soressi 2005), when it is present in the same sequences (Saint-Césaire, Le Moustier, La Quina). However, this does not appear to be the case at Roc de Combe, or has not at any rate been confirmed. If we limit our review to the published Discoid-denticulate Mousterian series, some of which have been dated, such as Saint-Césaire Egf/c.11-12 ( $42.4 \pm 4.3$ by TL: Mercier et al. 1993), La Quina c.6a ( $43.3 \pm 3.6$ by TL: Debénath and Jelinek 1999) and Rochers de Villeneuve c.N ( $>45.2 \pm 1.1$ AMS: Beauval et al. 2006), or non-dated series (Hauteroche, Sandougne, Brouillaud Combe-Grenal, Chadourne, Les Fieux), and without taking into account the contemporaneous potentially Discoiddenticulate Mousterian levels of le Moustier (c. I-H), currently undergoing reexamination (Gravina and Discamps 2013), this techno-complex, even if it comes after the MTA, is in the same biozone as isotopic stage 3 (Discamps, Jaubert, Bachellerie 2011) (fig. 12).

51 This Discoid-denticulate Mousterian clearly occurs before the Heinrich 4 event (38.6-40.2 calBP) and is very probably contemporaneous with the interstadial GI 9-11 
(40.2-43.3 calBP). The study of the associated fauna is now primordial in order to confirm this chrono-climatic attribution (Discamps et al. 2013).

Figure 12 - Table of the archaeosequences in south-western France with Discoid Denticulate Mousterian (DDM) industries. Only the succession of technocomplexes (colours), sterile levels (white) and speleothems (dashed lines) are taken into account. Each techno-complex has its colour.

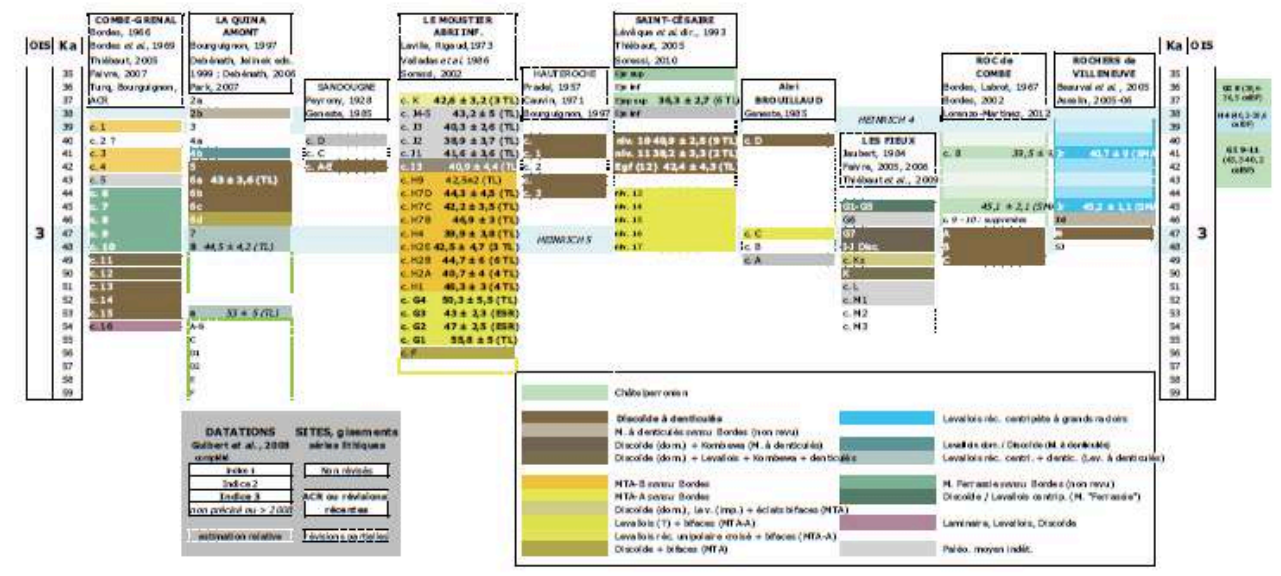

Finally, the last point to be raised here is the presence or not of several Levallois flakes at Roc de Combe, as part of an ultimate final Middle Palaeolithic occurrence after the Discoid-denticulate Mousterian, as is the case at Rochers de Villeneuve (Asselin 2005; Jaubert et al. 2011), and probably in other Charentian sequences (Les Plumettes: Airvaux, Beauval, Primault 2012; Discamps, Jaubert, Bachellerie 2011) and, subject to ongoing examinations, in other Aquitaine sequences. Indeed, at Roc de Combe, this Discoid-denticulate Mousterian is stratigraphically below a discreet series of Levallois flakes (Pelegrin 1995), which are overlain by a Chatelperronian (Bordes 2002). The systematic reevaluation of the sequences of south-western France argues in favour of discarding the model affiliating the MTA-A, then B and the Chatelperronian (Soressi 2002) and replacing it with another model (Gravina and Discamps 2013). Recent research points to a clear rupture with no transitional stage between the Late Middle Palaeolithic (MTA-A/B $\rightarrow$ M. Discoid-denticulate Mousterian $\rightarrow$ M. Levallois with large side scrapers) and the beginning of the Upper Palaeolithic (Bachellerie 2011; Bordes et al. 2011; Jaubert et al. 2011). Therefore, these techno-complexes follow on from each other without clear technical links, from the end of the Middle Palaeolithic until the beginning of the Recent Palaeolithic, casting serious doubt on any "Transitional" industry hypotheses. The Roc de Combe Mousterian undeniably contributes to backing up this new archaeo-stratigraphic schema. It is now essential to better characterize the variability and the chronology of these ultimate Mousterian cultures, which immediately preceded, or even accompanied (?) the beginning of the Chatelperronian. 


\section{BIBLIOGRAPHY}

AIRVAUX J., BEAUVAL C. et PRIMAULT J. 2012 - Le site du Moustérien récent de La Ganne à Mazerolles et les repaires d'hyènes des Plumettes et des Rochers de Villeneuve à Lussac-lesChâteaux (Vienne) : hypothèses sur la relation homme-carnivores. Préhistoire du Sud- Ouest, vol. $20, n^{\circ} 1$, p. 3-37.

ASSELIN G. 2005 - Étude techno-typologique et spatiale du matériel lithique du niveau J du site Moustérien des Rochers de Villeneuve, Lussac-les-Châteaux, Vienne (86). Mémoire de master 2, Université Bordeaux 1, $75 \mathrm{p}$.

ASTRUC J.-G. 1990 - Carte géologique de la France. Gourdon $n^{\circ}$ 832. Carte 1/50 000e. Orléans : éditions du BRGM.

BACHELLERIE F. 2011 - Quelle unité pour le Châtelperronien? Apport de l'analyse taphonomique et techno-économiques des industries lithiques de trois gisements aquitains de plein-air : le Basté, Bidart (Pyrénées-Atlantiques) et Canaule II (Dordogne). Thèse de doctorat, Université Bordeaux 1, $442 \mathrm{p}$.

BEAUVAL C., LACRAMPE-CUYAUBÈRE F., MAUREILLE B. et TRINKAUS E. 2006 - Direct radiocarbon dating and stable isotopes of the neandertal femur from Les Rochers- de-Villeneuve (Lussac-les-Châteaux, Vienne), Bulletins et mémoires de la Société d'Anthropologie de Paris, 18 (1-2).

BOËDA É. 1993 - Le débitage discoïde et le débitage Levallois centripète récurrent. Bulletin de la Société Préhistorique Française, 90, 6, p. 392-404.

BOËDA É. 1995 - Caractéristiques techniques des chaînes opératoires des niveaux micoquiens de Külna (Tchécoslovaquie). In : Les industries à pointes foliacées d'Europe centrale. Actes du colloque de Miskolc (10-15 septembre 1991). Paleo, supplément n²1, p. 57-72.

BOËDA É., GENESTE J.-M. et MEIGNEN L. 1990 - Identification de chaînes opératoires lithiques du Paléolithique ancien et moyen. Paleo, 2, p. 43-80.

BORDES F. 1961 - Typologie du Paléolithique ancien et moyen. Bordeaux : Imprimerie Delmas, Publ. de l'Institut de Préhistoire de l'Université de Bordeaux, 2 t., 85 p. 108 pl. h.t.

BORDES F. 1968 - La question périgordienne. In : La Préhistoire, problèmes et tendances. Paris : éditions du CNRS, p. 59-70.

BORDES F. 1972 - A tale of two caves. New York: Harper \& Row. p. 169.

BORDES F. 1981 - Vingt cinq ans après : le complexe moustérien revisité. Bulletin de la Société Préhistorique Française, 78, 3, p. 103-108.

BORDES F. 1984 - Leçons sur le Paléolithique. Tome 2 : le Paléolithique en Europe. Paris : éditions du CNRS (Cahiers du Quaternaire, 7).

BORDES F. et LABROT J. 1967 - La stratigraphie du gisement du Roc-de-Combe (Lot) et ses implications. Bulletin de la Société Préhistorique Française, LXIV, 1, p. 15-28.

BORDES J.-G. 2002 - Les interstratifications Châtelperronien/Aurignacien du Roc-de-Combe et du Piage (Lot, France). Analyse taphonomique des industries lithiques ; implications archéologiques. Thèse de doctorat, Université Bordeaux 1, $421 \mathrm{p}$.

BORDES J.-G., BACHELLERIE F., LE BRUN-RICALENS F. et MICHEL A. 2011 - Towards a new 'transition': New data concerning the lithic industries from the beginning of the Upper Palaeolithic in Southwestern France. In : A.P. Derevianko \& M. Shunkov Eds., Characteristc features 
of the Middle to Upper Palaeolithic Transition in Eurasia, Proceeding of the International Symposium, "Characteristc features of the Middle to Upper Palaeolithic Transition in Eurasia : Development of Culture and Evolution of Homo Genus" (July 4-10, Denisova Cave, Altai), Novosibirsk, Department of the Institute of Archaeology and Ethnography SB RAS, p. 116-129.

BOURGUIGNON L. 1997 - Le Moustérien de type Quina : nouvelle définition d'une technique. Thèse de doctorat, Université de Paris X-Nanterre, 2 t., 672 p.

BOURGUIGON L. et TURQ A. 2003 - Une chaîne opératoire de débitage Discoïde sur éclat du Moustérien à denticulés aquitain : les exemples de Champ Bossuet et de Combe-Grenal c. 14 ; In: M. Peresani (Ed.), Discoid lithic technology. Advances and implications. BAR International series, 1120, p. 131-152.

BOURGUIGNON L., FAIVRE J.-Ph et TURQ A. 2004.- Ramification des chaînes opératoires : une spécificité du Moustérien? Paleo, $\mathrm{n}^{\circ} 16$, p. 37-48.

BRENET M. et FOLGADO M. 2003 - Le débitage Discoïde du gisement des Forêts à Saint-Martin-deGurçon (Dordogne). In: M. Peresani (Ed.), Discoid Lithic technology. Advances and implications. BAR International Series, 1120 , p. 153-177.

CHALARD P., FAIVRE J.-Ph., JARRY M., JAUBERT J., MOURRE V. et TURQ A. 2007 - Espaces du Paléolithique moyen : témoins d'utilisation de silex allochtones en Quercy (France). In : J. Évin (Dir.), Un siècle de construction du discours scientifique en Préhistoire, volume I « Des idées d'hier... ». 26e congrès préhistorique de France. Congrès du Centenaire, Avignon-Bonnieux (21-25 septembre 2004). Paris : SPF, p. 217-235.

CHAMPAGNE et F. ESPITALIÉ R. 1967 - La stratigraphie du Piage : note préliminaire. Bulletin de la Société Préhistorique Française. 64, p. 29-34

DEBÉNATH A. et JELINEK A. J. (Dir.) 1999 - Nouvelles fouilles à La Quina (Charente). Résultats préliminaires. Gallia Préhistoire, T. 40, p. 29-74.

DELAGNES A. 2010 - Systèmes techniques et mobilité au Paléolithique moyen : interaction et implications diachroniques. Thèse d'Habilitation à Diriger des Recherches : Université Bordeaux 1, 229 p.

DELAGNES A. et RENDU W. 2011 - Shifts in Neandertal mobility, technology and subsistence strategies in Western France. Journal of Archaeological Science, 38, p. 1771-1783.

DISCAMPS E., JAUBERT J. et BACHELLERIE F. 2011 - Human choices and environmental contraints : deciphering the variability of large game procurement from Mousterian to Aurignacian times (MIS 5-3) in southwestern France. Quaternary Science Reviews, 30, 19-20, p. 2755-2775.

DISCAMPS E., SOULIER M.-C., BACHELLERIE F., BORDES J.-G., CASTEL J.-Chr. et MORIN E. 2013 Des faunes et des hommes : interactions entre environnements et cultures dans le Sud-Ouest de la France. In : J. Jaubert, N. Fourment et P. Depaepe, Transitions, ruptures et continuité en Préhistoire, XXVIIe congrès préhistorique de France - Bordeaux-Les Eyzies, 31 mai-5 juin 2010, p. 299-314.

FAIVRE J.-Ph. 2002 - Approche technologique du Moustérien du site des Fieux (Miers, Lot). Études des industries lithiques du niveau G7 (locus 1). Mémoire de maîtrise de l'Université de Toulouse-Le Mirail, $126 \mathrm{p}$.

FAIVRE J.-Ph. 2004 - L'industrie lithique moustérienne du niveau G7 des Fieux (Miers, Lot) : mobilité humaine et diversité des compétences techniques. Paleo, t. 16, p. 71-90.

FAIVRE J.-Ph. 2006 - L'industrie moustérienne du niveau Ks (locus 1) des Fieux (Miers, Lot) : mobilité humaine et diversité des compétences techniques. Bulletin de la Société Préhistorique Française, 103, 1, p. 17-32. 
FAIVRE J.-Ph. 2008 - Organisation techno-économique des systèmes de production dans le Paléolithique moyen récent du Nord-est Aquitain : Combe Grenal et Les Fieux. Thèse de doctorat, Université Bordeaux 1, 2008, 555 p.

FAIVRE J.-Ph., TURQ A., BOURGUIGNON L., BISMUTH T., COLONGE D., DEMARS P.-Y., JARRY M. et JAUBERT J., 2013 - Le Paléolithique moyen du Quercy : comportements techno-économiques et variabilités des productions lithiques. In : M. Jarry, J.-Ph. Brugal et C. Ferrier (Dir.), Modalités d'occupations et exploitation des milieux au Paléolithique dans le Sud-Ouest de la France : l'exemple du Quercy, Actes session C67, XVème Congrès de l'UISPP, Lisbonne, sept. 2006, Suppl. à Paleo, n 4, p. 197-235.

GENESTE J.-M. 1985 - Analyse lithique d'industries moustériennes du Périgord : une approche technologique du comportement des groupes humains au Paléolithique moyen. Thèse de doctorat, Université de Bordeaux I, 2 t.,

$572 \mathrm{p}$.

GENESTE J.-M. 1988 - Les industries de la grotte Vaufrey : technologie du débitage, économie et circulation de la matière première lithique, In : J.-Ph. Rigaud dir., La grotte Vaufrey.

Paléoenvironnement. Chronologie. Activités humaines, Mémoire de la Soc. Préh. Franç., XIX, Paris, p. 441-517.

GENESTE J.-M. 1991 - Systèmes techniques de production lithique : variation techno-économique dans les processus de réalisation des outillages paléolithiques. Techniques et cultures. « Préhistoire et technologie. Le geste retrouvé ", 17-18, p. 1-35.

GRAVINA B. et DISCAMPS E. 2013 - MTA B or not to 'B', that is the question? Poster ESHE September 2013, Wien.

GRAVINA B., BACHELLERIE F., DISCAMPS E., BORDES J.-G. et JAUBERT J. 2012 - A new ending for the Mousterian in south-western France? A revision of the Final Middle Paleolithic record in South-western France and its implications. Proceeding of the European Society for the study of Human Evolution, 2nd annual meeting, Bordeaux, 21-22 Sept. 2012, p. 89.

GRAYSON D.K. et DELPECH F. 2008 - The large mammals of Roc de Combe (Lot, France): the Chatelperronian and Aurignacian assemblages. Journal of Anthropological Archaeology, 27, p. 338-362.

GUIBERT P., BECHTEL F., BOURGUIGNON L., BRENET M., COUCHOUD I., DELAGNES A., DELPECH F., DETRAIN L., DUTTINE M., FOLGADO M., JAUBERT J., LAHAYE Ch., LENOIR M., MAUREILLE B., TEXIER J.-P., TURQ A., VIEILLVIGNE E. et VILLENEUVE G., 2008 - Une base de données pour la chronologie du paléolithique moyen dans le Sud-Ouest de la France. In : J. Jaubert, J.- G. Bordes et I. Ortega, Dir., Les sociétés du Paléolithique dans un Grand Sud-Ouest : nouveaux gisements, nouveaux résultats, nouvelles méthodes. Mémoire de la Société préhistorique française, XLVII [Journées SPF, Université Bordeaux 1, Talence, 24-25 novembre 2006], p. 19-40.

HEDGES R. E. M., HOUSLEY R. A., LAW I. A. et BRONK C. R. 1990 - Radiocarbon dates from the Oxford AMS system: Archaeometry datelist 10. Archaeometry, 32, p. 101-108.

INIZAN M.-L., REDURON-BOLLINGER M. et ROCHE H. 1995 - Technologie de la pierre taillée. Meudon : CREP, $199 \mathrm{p}$.

JARRY M., BERTRAN P., COLONGE D., LELOUVIER L.- A. et MOURRE V. 2007 - Les Bosses

(Lamagdelaine, Lot, France) : un gisement paléolithique moyen antérieur à l'avant-dernier Interglaciaire sur la moyenne terrasse du Lot. Paris, Travaux de la Société Préhistorique Française (7), 158 p. 
JAUBERT J. 1993 - Le gisement paléolithique moyen de Mauran (Haute-Garonne) : technoéconomie des industries lithiques. Bulletin de la Société préhistorique française, 90, p. 328-335.

JAUBERT J. 1994 - Les industries lithiques. In : C. Farizy, F. David et J. Jaubert (Dir.), Hommes et bisons du Paléolithique moyen à Mauran (Haute-Garonne). XXXe supplément à Gallia Préhistoire. Paris : éditions du CNRS, p. 73-167.

JAUBERT J. 2010 - Les archéoséquences du Paléolithique moyen en Poitou-Charentes. In : J. Buisson-Catil et J. Primault (dir.), Préhistoire entre Vienne et Charente - Hommes et sociétés du Paléolithique, Association des publications chauvinoises, Chauvigny (Mémoire XXXVIII), p. 51-55.

JAUBERT J. 2012 - Les archéo-séquences du Paléolithique moyen du Sud-Ouest de la France : quel bilan un quart de siècle après François Bordes? In : F. Delpech et J. Jaubert (Dir.), François Bordes et la Préhistoire. Actes du colloque international François Bordes, Bordeaux, 22-24 avril 2009, éditions du CTHS, coll. Documents Préhistoriques, n² 29, p. 235-253.

JAUBERT J. et MOURRE V. 1996 - Coudoulous, Le Rescoundudou, Mauran : diversité des matières premières et variabilité des schémas de production d'éclats. In : A. Bietti et S. Grimaldi (Eds.), Reduction Processes (chaînes opératoires) in the European Mousterian. Quaternaria Nova VI, p. 313-41.

JAUBERT J., BORDES J.-G., DISCAMPS E. et GRAVINA B. 2011 - A new look at the end of the Middle Palaeolithic sequence in Southwestern France. In : A.P. Derevianko \& M. Shunkov Eds., Characteristc features of the Middle to Upper Palaeolithic Transition in Eurasia, Proceeding of the International Symposium, "Characteristc features of the Middle to Upper Palaeolithic Transition in Eurasia : Development of Culture and Evolution of Homo Genus" (July 4-10), Denisova Cave, Altai), Novosibirsk, Department of the Institute of Archaeology and Ethnography SB RAS, p. 102-115.

JAUBERT J., LORBLANCHET M., LAVILLE H., SLOTT- MOLLER R., TURQ A. et BRUGAL J.-Ph. 1990 Les chasseurs d'Aurochs de La Borde. Un site du Paléolithique moyen (Livernon, Lot). Paris : éditions de la Maison des Sciences de l'Homme (dAf 28), $157 \mathrm{p}$.

KLARIC L. 2003 - L'unité technique des industries à burins du Raysse dans leur contexte diachronique. Réflexions sur la diversité culturelle au Gravettien à partir des données de La Picardie, d'Arcy-sur-Cure, de Brassempouy et du Cirque de la Patrie, Thèse de Doctorat en Préhistoire, Université de Paris I, 427 p.

LAHAYE Ch. 2005 - Nouveaux apports de la thermoluminescence à la chronologie du Paléolithique dans le Sud-Ouest de la France. Essai en milieu hétérogène et en présence de déséquilibres radioactifs dans les séries de l'uranium, Thèse de doctorat de l'Université Michel de Montaigne Bordeaux 3, 428 p.

LAVILLE H. 1969 - Climatologie et chronologie du Paléolithique du Périgord. Étude sédimentologique de dépôts en grottes et sous abris. Marseille, éd. du CNRS, Université de Provence 422 p. (Études quaternaires, 4).

LOCHT J.-L. 2004 - Le gisement paléolithique moyen de Beauvais (Oise). Thèse de doctorat, Université de Lille 1 ,

2004, 2 t., 209 p + 126 pl.

LOCHT J.-L. et SWINNEN C. 1994 - Le débitage discoïde du gisement de Beauvais (Oise) : aspects de la chaîne opératoire au travers de quelques remontages. Paleo, 6, p. 89-104.

LORENZO MARTINEZ M. 2012 - Le Moustérien Discoïde à denticulés du Roc-de-Combe (Lot) : caractérisation techno-économique de l'industrie lithique. Mémoire de master 2, Université Bordeaux $1,84 \mathrm{p}$.

MEIGNEN L. (Dir.) 1993 - L'abri des Canalettes : un habitat moustérien sur les grands causses (Nant, Aveyron). Fouilles 1980-1986. Paris : éditions du CNRS, 359 p. 
MERCIER N., VALLADAS H., JORON J.-L. et REYSS J.-L. 1993 - Datation par thermoluminescence du site préhistorique de la Roche à Pierrot à Saint-Césaire. In : Lévêque F., Backer A.M. \& Guilbaud M. (Eds), Context of a Late Neanderthal. Implications of Multidisciplinary Research for the Transition to Upper Paleolithic Adaptations at Saint-Césaire, Charente-maritime, France, Monographs in World Archaeology $\mathrm{N}^{\circ} 16$, Madison, Prehistory Press, p. 15-23.

MORALA A. 1984 - Périgordien et Aurignacien en Haut- Agenais : étude d'ensembles lithiques. Toulouse :École des Hautes Études en sciences sociales, Archive d'Écologie préhistorique, 7.

MOURRE V. 1994 - Les industries en quartz au Paléolithique moyen. Approche technologique de séries du Sud-Ouest de la France, Paris-X, Mémoire de Maîtrise, 111 p.

MOURRE V. 1996 - Les industries en quartz au Paléolithique. Terminologie, méthodologie et technologie. Paleo, 8, p. 205-223.

MOURRE V. 2003 - Discoïde ou pas Discoïde ? Réflexion sur la pertinence des critères techniques définissant le débitage Discoïde. In : M. Peresani (Ed.), Discoid lithic technology. Advances and implications. BAR International series, 1120, p. 1-18.

PARK S.J. 2007 - Systèmes de production lithique et circulation des matières premières au Paléolithique moyen récent et final. Une approche techno-économique à partir de l'étude des industries lithiques de La Quina (Charente). Thèse Université Paris X-Nanterre, 335 p.

PELEGRIN J. 1995 - Technologie lithique : le Châtelperronien de Roc-de-Combe (Lot) et de la Côte (Dordogne). Paris : éditions du CNRS, 279 p. (Cahier du Quaternaire, 20).

PERESANI M. (Dir.) 2003 - Discoid Lithic Technology. Advances and Implications. Oxford, British Archaeological Reports, 1120.

PERLÈS C. 1991 - Économie des matières premières et économie du débitage : deux conceptions opposées? In :

25 ans d'études technologiques en Préhistoire, bilan et perspectives. Juan-les-Pins : éditions APDCA, p. 35-45.

PEYRONY D. 1933 - Les industries «aurignaciennes » dans le bassin de la Vézère. Bulletin de la Société Préhistorique Française 30:543-559.

RICHTER D., DIBBLE H., GOLDBERG P., McPHERRON Sh. J. P., NIVEN L. SANDGATHE D., TALAMO S. et TURQ A. 2012 - The late Middle Palaeolithic in Southwest France: New TL dates for the sequence of Pech de l'Azé IV. Quaternary International, 294, p. 160-167.

RIGAUD J.-Ph. 2000 - Late Neanderthals in the South West of France and the émergence of the Upper Palaeolithic. In : C. B. Stringer, R. N. E. Barton \& J. Cl. Finlayson (Eds.) Neanderthals on the Edge. Papers from a conference marking the 150th anniversary of the Forbes' Quarry discovery, Gibraltar, Gibraltar, 1999, Oxbow Books, p. 27-31.

SÉRONIE-VIVIEN M. et SÉRONIE-VIVIEN M.-R. 1987 - Les silex du Mésozoïque nord-aquitain : approche géologique de l'étude des silex pour servir à la recherche. Supplément au Bulletin de la Société Linéenne de Bordeaux, XV.

SLIMAK L. 1999 - La variabilité des débitages discoïdes au Paléolithique moyen, diversité des méthodes et unité d'un concept - L'exemple des gisements de Baume Néron (Soyons, Ardèche) et du Champ-Grand (Saint-Maurice-sur- Loire, Loire). Préhist. Anthrop. Méditer., 7-8, (1998-1999), p. 75-88. 
SLIMAK L. 2003 - Les débitages Discoïdes moustériens : évolution d'un concept technologique. In: M. Peresani (Ed.), Discoid lithic technology. Advances and implications. BAR International series, 1120, p. 33-65.

SLIMAK L. 2004 - Les dernières expressions du Moustérien entre Loire et Rhône. Thèse Aix-Marseille I, Université de Provence, 649 p. +214 pl.

SORESSI M. 2002 - Le Moustérien de tradition acheuléenne du Sud-Ouest de la France. Discussion sur la signification du faciès à partir de l'étude comparée de quatre sites : Pech-de-l'Azé I, Le Moustier, La Rochette et la Grotte XVI. Thèse de doctorat, Université Bordeaux 1, 339 p.

SORESSI M. 2005 - Late Mousterian lithic technology: its implications for the place of the emergence of behavioural modernity and the relationship between behavioural modernity and biological modernity. In: D'Errico F., Backwell L. (Eds.), From tools to symbols: from early hominids to modern humans. Johannesburg: Witwatersrand University Press, p. 389-417.

SORESSI M. et PELEGRIN J. 2007 - Le Châtelperronien et ses rapports avec le Moustérien. In : Vandermeersch B. et Maureille B. (Eds), Les Néandertaliens, biologie et cultures, Paris : CTHS, Documents préhistoriques, 23, p. 283-296.

TAVOSO A. 1978 - Le Paléolithique inférieur et moyen du Haut-Languedoc. Gisements des terrasses alluviales du Tarn, du Dadou, de l'Agout, du Sor et du Fresquel. Université de Provence : éditions du Laboratoires de Paléontologie Humaine et de Préhistoire, Études Quaternaires, mémoire 5, 404 p.

TEXIER J.-P. 2009 - Histoire géologique de sites préhistoriques du Périgord: une vision actualisée. La Micoque, la grotte Vaufrey, le Pech de l'Azé I et II, La Ferrassie, L'abri Castanet, Le Flageolet, LaugerieHaute. Paris, éd. du CTHS 194 p. (Documents préhistoriques, 25).

THIÉBAUT C. 2005 - Le Moustérien à denticulés : variabilité ou diversité techno-économique ? Thèse de doctorat, Aix-Marseille 1, Université de Provence, 231p. + 635 p.

THIÉBAUT C. 2007 - Le Moustérien à denticulés des années cinquante à nos jours : définition et caractérisation. Bull. de la Soc. Préhist. française, T. 104, n 3, p. 461-482.

THIÉBAUT C., MEIGNEN L. et LEVÊQUE F. 2009 - Les dernières occupations moustériennes de Saint-Césaire (Charente-Maritime, France) : diversité des techniques utilisées et comportements économiques pratiques. Bulletin de la Société Préhistorique Française, 106, 4, p. 691-714.

TURQ A. 1992 - Le Paléolithique inférieur et moyen entre les vallées de la Dordogne et du Lot, Thèse ND, Université de Bordeaux I, 2 vol., 780 p., ill., $\mathrm{n}^{\circ} 778$.

TURQ A. 2000 - Le Paléolithique inférieur et moyen entre Dordogne et Lot. Paleo, Supplément $\mathrm{n}^{\circ}$ $2,456 \mathrm{p}$.

TURQ A. et JAUBERT J. 2008 - Le contexte culturel moustérien. In : B. Vandermeersch, J.-J. CleyetMerle, J. Jaubert, B. Maureille et A. Turq (dir.) 2008. Première humanité : gestes funéraires des Néandertaliens. Réunion des musées nationaux, Paris, p. 25-37.

TURQ A. et MORALA A. 2013 (Séronie-Vivien M. et M.-R., coll.) 2013 - Inventaire des silicifications du Quercy et de ses marges et des marqueurs lithologiques du nord-est aquitain : synthèse des données. In : Jarry M., J.-Ph. Brugal et C. Ferrier (Dir.), Modalités d'occupation et exploitation des milieux au Paléolithique dans le Sud-Ouest de la France : l'exemple du Quercy, colloque 67, XVème congrès de l'UISPP, Lisbonne, 2006, suppl. nº 4, Paleo. p. 159-180.

TURQ A., ANTIGNAC G. et ROUSSEL P. 1999 - Les silicifications coniaciennes du Sarladais et du Gourdonnais : inventaire et implications archéologiques. Paleo, 11, p. 145-160. 
TURQ A., DIBBLE H., FAIVRE J.-Ph., GOLDBERG P., McPHERRON Sh. J. P. et SANDGATHE D. 2008 Le Moustérien du Périgord : quoi de neuf? In : J. Jaubert, J.- G. Bordes et I. Ortega (Eds.), Les sociétés du Paléolithique dans un Grand Sud-Ouest de la France : nouveaux gisements, nouveaux résultats, nouvelles méthodes. Actes des journées de la SPF à Bordeaux (24-25 novembre 2006), mémoire XLVII de la SPF, p. 83-93.

\section{NOTES}

3. F. Bordes uses the name "the site of Roc de Combe" (title) or "Roc de Combe" (text) indifferently. Henri Laville opted for the latter option whereas the Dictionary of Prehistory directed by A. Leroi-Gourhan (PUF 1988) uses the title of the 1967 original article.

4. Following the initiative of V. Mourre, we now capitalize Discoid when referring to a debitage method defined by Boëda (1993): The term "Discoid" will not be used here to describe a disc shape, but always refers to a production schema: it is thus relevant to refer to Discoid debitage conception, where the capital letter accentuates this distinction (Jaubert and Mourre 1996 - note 1, p. 338).

5. Master 2 université Bordeaux 1: Lorenzo Martinez 2012.

\section{ABSTRACTS}

Roc de Combe (Lot, France) is one of the key sites concerning the Late Middle to Upper Palaeolithic transition in southwestern France. 1966' excavation, led by François Bordes, has yielded some Mousterian, Chatelperronian, Aurignacian and Gravettian rich assemblages. Here we present the analysis of the unpublished Mousterian lithic assemblages, studied by one of us during a Master degree. From this study, the belonging of this industry to a Denticulate-Discoid Mousterian has been confirmed, a technocomplex usually classically attributed to the final stage of the Mousterian. Several radiocarbon dates confirm this attribution. Finally, our analysis shows an original lithic raw material procurement strategy, due to the site location, peculiar to the Bouriane between Perigord and Quercy.

Roc de Combe est l'un des sites de référence pour étudier les modalités de passage Paléolithique moyen récent - Paléolithique supérieur initial (Châtelperronien) et Paléolithique supérieur ancien (Aurignacien ancien) dans le Sud-Ouest de la France. Fouillé par F. Bordes en 1966 et longtemps réputé pour une "interstratification " - désormais rejetée - servant la thèse de l'acculturation, il a fait l'objet d'une étude des niveaux attribués au Châtelperronien et à l'Aurignacien, mais les séries du Moustérien demeuraient jusqu'à ce jour identifiées, cependant non étudiées. Un récent travail universitaire mené par l'une d'entre nous (M.L.M.) permet désormais de disposer d'un bilan techno-économique et typologique confirmant l'attribution de cette série au Moustérien de débitage Discoïde à denticulés, techno-complexe qui clôt dans le Sud-Ouest de la France nombre d'archéo-séquences. La présente étude donne les premières données numériques relatives à cette série inédite, la positionne dans un cadre chrono-culturel et son contexte régional, en insistant sur un statut pétrographique relativement original propre à la Bouriane, région faisant la liaison entre Périgord et Quercy. 
INDEX

Keywords: Late Middle Paleolithic (LMP), Isotopic stage 3 (MIS 3), Discoid, Denticulate Mousterian, Perigord, Quercy, lithic technology, raw material

Mots-clés: Paléolithique moyen récent, stade isotopique 3, Discoïde, Moustérien Discoïde à denticulés, Périgord, Quercy, matières premières, techno-économie lithique

\section{AUTHORS}

\section{MARIA LORENZO MARTINEZ}

39 rue de la Garde, FR-63000 Clermont-Ferrand - lamaruxina@gmail.com

\section{JEAN-GUILLAUME BORDES}

PACEA UMR 5199 CNRS, Université de Bordeaux, Bâtiment B8 Allée Geoffroy Saint-Hilaire CS 50023 FR-33615 Pessac Cedex - jg.bordes@pacea.u-bordeaux1.fr ; j.jaubert@pacea.u-bordeaux1.fr

\section{JACQUES JAUBERT}

PACEA UMR 5199 CNRS, Université de Bordeaux, Bâtiment B8 Allée Geoffroy Saint-Hilaire CS 50023 FR-33615 Pessac Cedex - jg.bordes@pacea.u-bordeaux1.fr ; j.jaubert@pacea.u-bordeaux1.fr 